\title{
OS CASTROS NO TEMPO DAS VILLAE. FUNCIÓNS NON MILITARES DOS CASTROS NO VAL DO SARRIA NA ALTA IDADE MEDIA*
}

\author{
CARlos Lixó GómeZ \\ Universidade de Santiago de Compostela \\ ORCID iD: http://orcid.org/0000-0002-1202-7820
}

\begin{abstract}
* O presente texto realizouse no marco da elaboración da tese de doutoramento $O$ xurdimento dos castelos na Galiza medieval (ss. VIII-XIII), para a que se conta cun contrato do Programa de Formación del Profesorado Universitario (FPU) do Ministerio de Educación, Cultura e Deporte, baixo a dirección do Dr. Ermelindo Portela e Silva e o Dr. José Miguel Andrade Cernadas no Grupo de Investigación GI-1507 "Medievalismo: Espazo, imaxe e cultura".
\end{abstract}

Copyright: C 2018 CSIC. La edición electrónica de esta revista se distribuye bajo los términos de una licencia de uso y distribución Creative Commons Reconocimiento 4.0 Internacional (CC BY 4.0).

Cómo citar/Citation: Carlos Lixó GómEz, "Os castros no tempo das villae. Funcións non militares dos castros no val do Sarria na Alta Idade Media", Cuadernos de Estudios Gallegos, 65, núm. 131 (2018), págs. 37-72, https://doi.org/10.3989/ceg.2018.131.02 


\title{
OS CASTROS NO TEMPO DAS VILLAE. FUNCIÓNS NON MILITARES DOS CASTROS NO VAL DO SARRIA NA ALTA IDADE MEDIA
}

\begin{abstract}
RESUMO
A densidade e as particularidades que os poboados da Idade do Ferro teñen en Galiza convertéronos en elementos estruturadores do territorio e portadores dunha fortísima carga simbólica ao longo dos séculos, até hoxe. O duradeiro e irregular proceso de desaparición do modelo castral cara a unha rede campesiña de asentamentos abertos nos vales e chairas parece terse culminado na Alta Idade Media, cando as villae, predecesoras das aldeas e parroquias de época feudal, son xa a célula de poboación hexemónica. No presente traballo analizaremos o papel social que tiñan os castros no val do Sarria nesa altura baseándonos na análise dos documentos do tombo de Samos e no estudo histórico da paisaxe.

Palabras Clave: castros; villae; Alta Idade Media; Galiza; tombo de Samos; Sarria.
\end{abstract}

\section{LOS CASTROS EN EL TIEMPO DE LAS VILLAE. FUNCIONES NO MILITARES DE LOS CASTROS EN EL VALLE DEL SARRIA EN LA ALTA EDAD MEDIA}

\section{RESUMEN}

La densidad y las particularidades que los poblados de la Edad del Hierro tienen en Galicia los han convertido en elementos estructuradores del territorio y portadores de una fortísima carga simbólica a lo largo de los siglos, hasta hoy. El duradero e irregular proceso de desaparición del modelo castral hacia una red campesina de asentamientos abiertos en los valles y llanuras parece haberse culminado en la Alta Edad Media, cuando las villae, predecesoras de las aldeas y parroquias de época feudal, son ya la célula de población hegemónica. En el presente trabajo analizaremos el papel social que tenían los castros en el valle del Sarria en esa altura basándonos en el análisis de los documentos del tumbo de Samos y en el estudio histórico del paisaje. Palabras Clave: castros; villae; Alta Edad Media; Galicia; tumbo de Samos; Sarria.

\section{HILLFORTS IN THE TIME OF VILLAE. NON-MILITARY FUNCTIONS OF SARRIA VALLEY HILLFORTS DURING THE EARLY MIDDLE AGES}

\section{ABSTRACT}

The density and the particularities that Iron Age hillforts show in Galicia turned them into main elements in territory organization and in social symbolism throughout the centuries. The lasting and irregular process of the disappearance of the closed hillfort model towards a network of open settlements in the valleys and plains seems to have been completed in the Early Middle Ages, when villae, predecessors of villages and parishes of feudal times, were already the hegemonic population centers. In this paper we will study the social role that hillforts had in the Sarria valley at that time, basing our analysis on documents from the Samos documental collection and on the study of the landscape.

KEY wORDs: hillforts; villae; Early Middle Ages; Galicia; Samos documental collection; Sarria. 
Recibido/Received: 11/12/2017

Aceptado/Accepted: 16/04/2018

$\mathrm{O}$

$\mathrm{s}$ castros son referentes identitarios na sociedade galega actual e fórono na pasada, como escenarios dos relatos populares que explicaron o mundo baseándose na experiencia vital campesiña acumulada ao longo das xeracións. Dito coa palabra precisa de X. Ayán Vila: cada castro é un espazo definitorio na semantización simbólica da paisaxe cultural e mailo hábitat rural tradicional $^{1}$. M. Llinares, nos seus estudos sobre o imaxinario popular galego, explicou como estes enclaves son o lugar de residencia e de manifestación de todo un rico elenco de criaturas máxicas ${ }^{2}$. Alí agochábanse tesouros e abríanse portas de túneles misteriosos; alí sucedían cousas que só podían suceder alí. Nucleaban o relato construído para dar sentido ao espazo habitado. Por iso non se poden tratar apenas como restos materiais da Idade do Ferro.

No presente artigo pretendemos pór máis un gran de area no coñecemento do que aconteceu cos castros despois do tempo dos $\operatorname{castros}^{3}$, achegarnos no posíbel ao seu papel na Alta Idade Media, nomeadamente nos séculos X e XI, período cronolóxico en que nos centramos aínda recorrendo, cando oportuno, a algún texto anterior ou posterior. A documentación previa ao ano mil mostra as villae como o soporte substancial da organización do territorio galego, como teñen analizado E. Portela e M. C. Pallares ${ }^{4}$, e os seus límites, descritos en ocasións con abraiante minuciosidade, son presentados como antigos, pondo de manifesto que o modelo está nesas alturas xa consolidado e que a súa xestación vén de ben atrás.

\footnotetext{
1 Xurxo Ayán Vila, "Os castros despois dos castros: Un espazo simbólico na paisaxe rural tradicional galega”, en Paula Ballesteros Arias (coord.), Encontros coa etnografia, Noia, Toxosoutos, 2005, páx. 65. 2 Mar Llinares García, Mouros, ánimas, demonios: el imaginario popular gallego, Madrid, Akal, 1990, páxs. 115-132.

3 Esta idea do estudo dos castros unha vez finalizado o tempo da súa vixencia aparece en Álvaro ArIZAGA Castro e Xurxo Ayán Vila, "Etnoarqueología del paisaje castreño: La segunda vida de los castros", en F. J. Fernández García et al. (eds.), Los pueblos de la Galicia céltica, Madrid, Akal, 2007, páxs. 445-531 e en X. Ayán Vila, "Os castros despois dos castros...". Con esta idea ten a ver tamén o libro: Marcos MARTINÓN-Torres, O megalitismo despois do megalitismo. Arqueoloxía e historia dos megalitos galegos a través das fontes escritas (s. VI-s. XIX), Valga, Concello de Valga, 2011.

4 Ermelindo Portela Silva e María Carmen Pallares Méndez, "La villa, por dentro. Testimonios galaicos de los siglos X y XI”, Studia historica. Historia medieval, 16 (1998), páxs. 13-43.
} 
No entanto, o tecido que se ve nos diplomas altomedievais non xurdiu ex novo, senón que se formou a partir dun outro anterior ao que rematou por substituír, ao longo dun proceso de transición que non foi marcado por episodios desocupación e reocupación, senón sobre todo pola continuidade ${ }^{5}$.

$\mathrm{O}$ facto de que un bo número dos castelos que posteriormente se terían erixido na Galiza, superpóndose sobre esa rede previa, escollesen localizacións ocupadas antigamente por castros, deu lugar a un especial interese no estudo da reutilización militar destes enclaves, ou até do seu posíbel mantemento ininterrompido como locais defensivos. No entanto, non debemos caer nunha falsa simetría: que houbese castelos que se construísen sobre castros non quere dicir que na maior parte dos castros tivese habido un castelo. Naturalmente, esa reocupación existiu nalgunhas ocasións, moi relevantes por acaso ${ }^{6}$, como é esperábel aínda que só for polo facto de que ambos fenómenos responden a un modelo de fortificación en altura, de maneira que estudos nesa liña son e deben ser feitos. Mais de entre os castros de que as fontes altomedievais nos fan chegar información só algúns dan probas certas de teren tido funcións militares neses momentos. Non nos centraremos neles aquí7; o que veremos a través dalgúns exemplos é con que roles fican precisamente a outra grande parte de castros que se integrarían na paisaxe medieval sen seren xa utilizados como fortificacións efectivas.

Optamos para iso por un estudo de caso a unha escala relativamente reducida, centrándonos nunha área do centro sur da provincia de Lugo, o val do Sarria, que aínda que limitada dun punto de vista xeográfico permítenos unha pescuda máis exhaustiva e segura de cara á realización dunha análise en profundidade. $\mathrm{O}$ motivo fundamental de tomarmos ese espazo concreto e non outro con calidades semellantes é que ao pé mesmo do río Sarria se encontra a orixe da nosa fonte documental principal: o mosteiro de San Xulián de Samos. O seu tombo garda numerosos diplomas datados entre 785 e 1209 constituíntes dun dos conxuntos máis ricos para o estudo da sociedade altomedieval galega. Será o uso dese corpus o que nos permita desenvolver unha metodoloxía de lectura histórica da paisaxe, que E. Portela e M. C. Pallares definiron como a adquisición de coñecemento histórico novo mediante

\footnotetext{
5 Ermelindo Portela Silva e María Carmen Pallares Méndez, "Galicia á marxe do Islam, continuidade das estructuras organizativas no tránsito á Idade Media” en María Xosé Fernández Cerviño e Gerardo Pereira Menaut (coords.), Galicia fai dovs mil anos. O feito diferencial galego na Historia, vol. I, Santiago de Compostela, Museo do Pobo Galego - A Editorial da Historia, 1997, páxs. 35-58.

6 E. Portela e M. C. Pallares explicaron o ilustrativo caso do castrum Baroncelli, deshabitado no século $\mathrm{X}$, funcionando de límite na súa contorna, dando o seu nome de Baroncelli ao territorio e ás vilas asentadas nel, até que dous séculos máis tarde, sen solución de continuidade, se construíu sobre o vello emprazamento o castelo de Monterrei. E. Portela Silva e M. C. Pallares Méndez, "Galicia á marxe do Islam...", páxs. 445-448.

7 Porén si o faremos en futuras ocasións, ao ser un tema do que nos estamos a ocupar na nosa tese de doutoramento en marcha.
} 


\begin{abstract}
el vaciamiento previo sobre el paisaje del caudal informativo contenido en los testimonios escritos que vienen, de este modo, a fundirse con los no escritos para dar cuenta, sobre un espacio determinado, de lo que a la historia importa: la actividad social en el tiempo ${ }^{8}$.
\end{abstract}

No percorrer do tempo, estes castros tiñan perdido as súas funcións orixinais, mais lonxe de esvaecérense como se esvaeceu o seu cometido militar, mudaron e pasaron a formar parte do territorio e da sociedade dunha outra maneira. Se cadra podería parecer esaxerado afirmar, como fan Arizaga e Ayán ${ }^{9}$, que a inmensa maioría dos asentamentos medievais ou coinciden en localización cun enclave castrexo ou se encontran moi próximos a el. Mais non se trata dunha ocorrencia. Xa o xeógrafo A. Bouhier no seu clásico ensaio xeográfico da Galiza expuña unha idea semellante: se, a cada parroquia non lle corresponde obrigatoriamente un castro, en troques, a cada castro correspóndelle con moita frecuencia unha parroquia $^{10}$. E se efectivamente é innegábel a constante relación dos espazos relevantes para as comunidades campesiñas coas vellas fortificacións pagás, canto máis non o sería nunha Idade Media cunha ocupación humana moito menos intensa e coa vistosidade dunhas estruturas materiais con mil anos menos de destrución no seu lombo.

Estamos entón ante dous factores que se retroalimentan: a nomeada carga simbólica destes lugares e a súa extraordinaria densidade no territorio. Revisando o inventario arqueolóxico oficial da Xunta de Galiza ${ }^{11}$ relativo aos concellos do val do Sarria ${ }^{12}$ contabilizamos un total de 161 enclaves identificados como castros polo equipo arqueolóxico, fronte a só 10 xacementos catalogados como medievais,

\footnotetext{
8 Ermelindo Portela Silva e María Carmen Pallares Méndez, "Estructuras agrarias y cambio social en la Galicia de la Edad Media. Una propuesta de lectura histórica del paisaje” en Mercedes López-Mayán Navarrete e Carlos J. Galbán Malagón (coords.), Del documento escrito a la evidencia material: Actas del I Encuentro Compostelano de Arqueología Medieval (Santiago de Compostela, 22, 23 y 24 de marzo de 2006), Santiago de Compostela, Lóstrego, 2007, páx. 39.

9 Á. Arizaga Castro e X. Ayán Vila, “Etnoarqueología del paisaje castreño...”, páx. 492.

${ }^{10}$ Abel Bouhier, Galicia: Ensaio xeográfico de análise e interpretación dun vello complexo agrario, Santiago de Compostela, Consellería de Agricultura, Gandaría e Política Agroalimentaria - Caixanova, 2001, páx. 1186.

${ }^{11}$ Inventario do Patrimonio Arqueolóxico de Galicia, depositado na Dirección Xeral de Patrimonio Cultural da Xunta de Galicia, Santiago de Compostela, inédito.

12 Revisamos os actuais concellos de Sarria, Samos, O Incio, Triacastela, Láncara, Paradela e A Pobra do Brollón, xa que é neles onde se localizan os castros da contorna do mosteiro de Samos mencionados no seu tombo. Se substituísemos A Pobra do Brollón polo Páramo coincidiría exactamente coa comarca administrativa actual de Sarria, o que nos fala dunha certa coherencia xeográfica diacrónica. Unha sintética listaxe sobre as demarcacións nesta área entre os séculos VI e XX d.C foi feita en Xaime Félix LóPEZ ARIAS e Ricardo Segundo López Méndez, "Organización territorial das terras de Sárria (s. VI a s. XX)”, Boletín do Seminario de Estudos Sarriaos “Francisco Vázquez Saco”, 21 (2016), páxs. 105-124.
} 
deixando fóra templos, pontes e necrópoles. Tendo en contra que se trata dunha área de $935 \mathrm{~km}^{2}$, podemos calcular unha densidade de 0,7 castro $/ \mathrm{km}^{2}$ e por tanto de media un castro cada $5,8 \mathrm{~km}^{2}$. Nos asentamentos medievais os números baixan até 0,01 asentamento $/ \mathrm{km}^{2}$ e un asentamento cada $93,5 \mathrm{~km}^{2}$.

En calquera caso estas cifras, aínda que moi ilustrativas, non son conclusivas ${ }^{13}$. Queremos dicir con isto que o rexistro da Xunta, de enorme utilidade, é froito das condicións en que foi elaborado e sobre todo da funcionalidade para a que se deseñou, que non é outra que estabelecer unha listaxe extensiva que recolla todos os xacementos arqueolóxicos posíbeis e os seus trazos básicos para garantir a súa xestión e protección. De paso, proporciona unha información xeral a grande escala que permite aos investigadores contar cun punto de partida cando se dispoñen facer aproximacións máis concretas. Cando tales aproximacións teñen lugar non é estraño que as intervencións arqueolóxicas intensivas sobre xacementos concretos ou pequenas áreas acaben por achegar periodizacións e análises máis precisas, corrixindo en ocasións algunhas adscricións á Idade do Ferro de emprazamentos que se integrarían exclusiva ou complementariamente no período xa medieval ${ }^{14}$, erros no entanto comprensíbeis ante a alta densidade dos castros e a finitude dos medios económicos e humanos.

É xa amplamente recoñecida a ocupación e reocupación de castros en período xermánico, non só baseándose na famosa mención de Idacio sobre os castella

\footnotetext{
${ }^{13}$ Os datos van mudando progresivamente ao apareceren máis xacementos que, previa análise dos arqueólogos da Xunta, pasarán a ser ingresados no catálogo. Este é o caso, por exemplo, do castro de Santo Antonio, en Samos, de cuxa (re)descuberta e posterior indexación se fai eco o xornal La Voz de Galicia. Xosé Ramón Penoucos, "Un incendio descubre un castro en Samos", La Voz de Galicia, 07/11/2017, dispoñíbel en liña: <https://www.lavozdegalicia.es/noticia/lugo/samos/2017/11/07/incendio-descubrecastro-samos/0003_201711L7C7991.htm> [Última consulta 07/11/2017].

${ }^{14}$ A arqueoloxía, pola súa natureza sostida no traballo técnico, é unha disciplina en constante e rápida evolución. Mesmo no caso de facermos un traballo partindo dun enfoque arqueolóxico os resultados non serían, como con certeza tampouco o son neste, definitivos, e as reinterpretacións dos xacementos poderían darse nos dous sentidos, non só descubrindo a hipotética medievalidade dalgúns deles senón tamén cuestionándoa cando se cría posíbel. O castro de Formigueiros, que se encontra na nosa área de estudo e é mencionado até en catro ocasións no Tombo de Samos entre 1031 e 1098, é un caso que se ten considerado repetidas veces como de ocupación medieval. No entanto, recentemente tense concluído que a revisión dos materiais retirados nas escavacións deu "resultados negativos para os obxectivos marcados" na procura de restos medievais "en canto que mostraron a ausencia de materiais cerámicos posteriores ao século I d.C.", a pesar de que en análises anteriores se tiña proposto que algúns materiais "mostraban a ocupación "tardía' do castro", Carlos Tejerizo García e Mario Fernández Pereira, Prospección arqueolóxica do poboamento de época tardorromana e sueva no Sueste da Galiza, informe inédito depositado na Dirección Xeral do Patrimonio Cultural da Xunta de Galicia, Santiago de Compostela, 2018. Agradecémoslle a Carlos Tejerizo García, Mario Fernández Pereira e Celtia Rodríguez, director e membros do equipo técnico do proxecto Sputnik Labrego. Resilencia e resistencia da sociedade labrega galega en momentos de perigo, do que tamén nós formamos parte, a didáctica á hora de explicaren ante os nosos ollos inexpertos as súas interpretacións das cerámicas.
} 
tutiora ${ }^{15}$ senón tamén en fundamentos arqueolóxicos ${ }^{16}$. Aínda máis, até se ten proposto a existencia de poboados fortificados en altura que teñan cronoloxías talvez non anteriores a estes primeiros períodos medievais ${ }^{17}$, como poderían ser o enigmático caso de Castro Valente ${ }^{18}$ ou o poboado sueste de castro Laboreiro, cuxa cronoloxía se ten barallado para o período xermánico ou para os primeiros anos de Reconquista ${ }^{19}$ e que se encontra no baixo dunha aba do monte en cuxo cumio domina o castelo de Castro Laboreiro ${ }^{20}$. Na nosa área de estudo, en base

${ }_{15}$ Trátase dun fragmento da Crónica de Idacio de Chaves, que viviu no século V e foi vehementemente
contrario ao dominio dos suevos, en que expón que "Sueui, sub Hermerico rege, medias partes Gallaeciae
depraedantes, per plebem, quae castella tutiora retinebat, acta suorum partim caede, partim captiuitate,
pacem quam ruperant familiarum quae tenebantur redhibitione restaurant", Hydace, Chronique, (ed. Alain
Tranoy, 1974), t. I, París, Éditions du Cerf, páx. 131, parágrafo 91. Este texto deu lugar a unha teoría pola
cal algúns castros tiñan sido ocupados puntualmente naqueles momentos de maior axitación política e
militar. A intervención arqueolóxica ten demostrado que no entanto, nalgúns dos que foron ocupados no
período suevo, a secuencia non é de uso puntual e belicoso senón que manifestan signos de estabilidade,
como é o caso do coñecido castro de Viladonga, aparentemente utilizado desde o século III até o VI d. C.,
José Avelino GutiérREz GonzÁLEz, "Del Castrum al Castellum. Los castros entre la Antigüedad y la Edad
Media", en Miguel Ángel de Blas Cortina e Ángel Villa Valdés (coords.), Los poblados fortificados del
noroeste de la Península Ibérica: Formación y desarrollo de la cultura castreña. Coloquios de Arqueo-
logía en la cuenca del Navia. Homenaje al Prof. Dr. José Manuel González y Fernández-Valles, Navia, Ayuntamiento de Navia, 2002, páx. 305.

16 Ademais do xa citado traballo de A. Gutiérrez González, "Del Castrum al Castellum..." podemos propor como dous exemplos entre moitos o de Tomás Rodríguez Fernández, "El fin del mundo fortificado y la aparición de las 'aldeas abiertas'. La evidencia del Centro-Oriente de Lugo (Samos y Sarria)", Espacio, Tiempo y Formas. Serie I. Prehistoria y Arqueología, 7 (1994), páxs. 153-189 e o de Jorge López QuirogA e Mónica Rodríguez Lovelle, "Castros y castella tutiora de época sueva en Galicia y Norte de Portugal. Ensayo de inventario y primeras propuestas interpretativas”, Historia Antiqua, 23 (1999). Dunha óptica diferente e aplicándose ao espazo entre Doutro e Miño, en Jorge López Quiroga, El final de la Antigüedad en la Gallaecia: La transformación de las estructuras de poblamiento entre Miño y Duero (siglos $V$ al $X$ ), A Coruña, Fundación Pedro Barrié de la Maza, 2004, proponse unha cronoloxía máis ampla en que os castros como unidades de poboamento fundamentais se manterían segundo o autor até despois do século $\mathrm{X}$, momento en que se situaría a fin da Antigüidade. Tal sistema, articulado arredor de grupos monásticofamiliares, aplicaríase tamén á área de Samos, de maneira que o modelo de organización das comunidades rurais da súa contorna estaría baseado nunha "clara influencia e inspiración fructuosiana", Jorge LóPEZ Quiroga e Mónica Rodríguez Lovelle, "Un modelo del poblamiento rural en la Galicia interior (s. V-X): El territorio en torno a la depresión de Sarria y al monasterio de Samos", Boletín do Museo Provincial de Lugo, 9 (1999-2000), páx. 180.

17 Mario Fernández Pereiro, "Mais lá da Cultura Castreja: castros ex-novo durante a antiguidade tardia no noroeste da Gallaecia" en Alia Vázquez Martínez et al. (eds.), (Re)escribindo a Historia: Achegas de novos investigadores en Arqueoloxía e Ciencias da Antigüidade, Santiago de Compostela, Andavira, 2017, páxs. 287-292.

18 David Fernández Abella, "Castro Valente, una fortificación de control del río Ulla" en Raúl Catalán, Patricia Fuentes e José Carlos Sastre (eds.), Fortificaciones en la tardoantigüedad: élites y articulación del territorio (siglos V-VIII d.C.), Madrid, La Ergástula, 2014, páxs. 393-398.

19 A. Lima considera que ten a ver co período xermánico mentres A. M. Baptista aposta máis ben pola época da primeira Reconquista, Alexandra Cerveira Pinto S. LimA, Castro Laboreiro: Povoamento e organização de um território serrano, Melgaço, Instituto de Conservação da Natureza, 1996, páxs. 85-89.

${ }^{20}$ A estrutura que se mantén en pé responde a unha arquitectura de tempo do rei Don Dinís de Portugal, aínda que se conserva documentación que nos fala del de maneira explícita xa a mediados do século XII, 
aos materiais encontrados, para aqueles castros de ocupación tardía tense proposto un último nivel de ocupación arredor do século $\mathrm{V}$ d.C., prolongado nalgún caso até o VI d. C., momento a partir do cal o poboado castrexo ya no es un lugar de habitación colectiva ${ }^{21}$. Sexa como for, afondar en análises deste tipo, o que sen dúbida resultaría enriquecedor, escapa das nosas capacidades no marco do presente artigo, que no entanto achamos razoábel por si mesmo.

A clave para afrontar o xa superado debate entre arqueoloxía e historia recae na colaboración e atención mutua, partindo da asunción honesta dos propios límites. Os nosos no presente traballo están claros: queremos ver o que nos din as fontes documentais sobre aqueles castros que non dan mostra de seren castelos funcionais no período proposto. Con independencia de que nós nas nosas construcións teóricas os poidamos clasificar como castros estritamente prehistóricos ou de período xermánico, de se os restos que encontramos neles poñen a data final no século I a. C. ou ao $\mathrm{V}$ d. C., veremos como foron readaptados nun momento posterior en que as súas funcións xa non eran as orixinais. Ao lado dos datos espidos, as tres decenas de castros que aparecen nomeados no Tombo de Samos non parecen tantos en relación aos 161 catalogados no territorio. Apenas chegou até nós por vía documental unha pequena parte dun conxunto moi amplo que exercía o seu papel na sociedade, ou máis ben varios papeis e a diversas escalas. Mais podemos ver, para alén das propias realidades materiais que agochan baixo a terra, unha pequena manifestación de como as persoas que vivían no período que denominamos hoxe Alta Idade Media racionalizaban a súa convivencia cos vellos poboados a través da chave coa que abrimos o mundo, a palabra.

\section{O CASTRO COMO REFERENTE ESPACIAL}

Ao longo do tempo as persoas relacionáronse coa contorna que as rodeou con naturalidade, e é de tal interacción espontánea que teñen xurdido maneiras moi diversas de percibila. O. F. Bollnow sería quen de as agrupar baixo o concepto único de espazo vivencial: un espazo no que existe un punto central, no que os lugares son cualitativamente diferentes entre si, no que conviven transicións fluídas e límites radicais e no que, sobre todo, a visión do ser humano, a súa experiencia vital e a súa actuación sobre o terreo significan moito máis do que as realidades físicas ${ }^{22}$. Tendo en conta iso, M. Llinares vai un paso alén e afirma que por tanto o espazo ocupado directamente polas persoas é marcado dunha maneira diferente

Carlos Alberto Ferreira de Almeida, Alto Minho, Lisboa, Presença, 1987, páx. 182. Desde o alto do cerro onde se encontra o castelo ao poboado altomedieval hai un desnivel de case 150 metros. Estamos a traballar nesta cuestión na nosa tese de doutoramento en marcha.

21 T. Rodríguez Fernández, “El fin del mundo fortificado...”, páx. 160 e páx. 175.

22 Otto Friedrich Bollnow, Hombre y espacio, Barcelona, Labor, 1969, páxs. 23-25. 
a outros espazos que coñecen en maior ou menor medida porén que non domi$\operatorname{nan}^{23}$. As descricións e delimitacións de territorios recolleitas nos documentos deste período evidencian de inmediato que los indicadores de localización -la circunscripción administrativa, el río más próximo, el monte, el castro-combinan elementos naturales y culturales para señalar el territorio que los hombres ocupan, es decir, explotan y habitan ${ }^{24}$. Estas son as palabras que utilizan Portela e Pallares para explicaren como a construción do espazo habitado na Idade Media non estabelece categorías ríxidas entre o natural e o humano nin entre o xeográfico e o político, recorrendo por igual a todo aquilo que pode ser percibido e utilizado para racionalizar o marco de desenvolvemento práctico da vida.

Un grande número dos castros que aparecen na documentación galega deste período, naturalmente tamén algúns no tombo de Samos, faino de maneira referencial, isto é, como unha marca recoñecíbel cuxa mención axuda a situar un outro lugar. Trátase en boa medida de breves aclaracións, como nunha doazón datada de 1098 en que se inclúe a villa de Abiti de radice de illo castro ${ }^{25}$, isto é, a villa da Vide, que sobrevive hoxe como parroquia en Monforte de Lemos, ao pé do castro. A preposición escolleita, de radice, indícanos de maneira literal a situación do castro en altura, en contraste co asentamento que se sitúa no baixo, aínda que non podemos descartar por completo a interpretación de Varela Sieiro segundo a cal é posíbel que se remita non só á elevación do lugar senón tamén á altura dos muros das antigas fortificacións castrexas ${ }^{26}$. Sexa como for, neste caso aí está, doadamente localizábel, a fortificación arredondada característica da Idade do Ferro enriba dun pequeno monte sobre o val en que se asenta A Vide. A mención é tan concisa que nin sequera se proporciona un topónimo concreto para o enclave, podendo ser que xa non o tivese nesa altura e que recibise o mesmo que a propia villa, mais mesmo en caso de que un outro antigo nome fose aínda usado considerouse un detalle irrelevante na redacción. $\mathrm{O}$ castro interesa porque está no alto e porque calquera persoa implicada sabería con certeza que na cima de Abiti se encontran aquelas vellas ruínas.

Este tipo de mencións utilízanse por norma xeral no marco dunha fórmula referencial que pode incluír tamén un río e un territorio ou val, e que recorre aos montes de maneira semellante aos castros, chegándose a utilizar en diferentes documentos os dous termos, mons e castrum, de maneira indistinta para falar dun

\footnotetext{
${ }^{23}$ M. Llinares García, Mouros, ánimas, demonios..., páx. 115.

${ }^{24}$ E. Portela Silva e M. C. Pallares Méndez, "Estructuras agrarias...”, páx. 41.

25 Manuel Lucas Álvarez, El Tumbo de San Julián de Samos (Siglos VIII-XII). Estudio introductorio. Edición diplomática. Apéndices e índices, Santiago de Compostela, Caixa Galicia, 1986, doc. núm. S-19, páx. 471, ano 1098.

${ }^{26}$ Xaime Varela Sieiro, Léxico cotián na alta Idade Media de Galicia: A arquitectura civil, Santiago de Compostela, Universidade, 2008, páx. 58.
} 
mesmo lugar ${ }^{27}$. Un exemplo ilustrativo na nosa área sería et est ipsa villa vocabulo Teymoi in territorio Gallecie, in valle Homano, rivulo discurrente Homano, subtus monte Eira Castro $^{28}$, onde se nomea nesa única mención un referente con ambos termos, monte e castro. En base a construcións lingüísticas deste tipo elaborouse unha teoría segundo a cal a aparición da mención $s u b$ / subtus / ad radicem castrum e, por extensión, sub / subtus / ad radicem monte ou alpe, non nos estaría a dar unha referencia xeográfica, senón que implicaría o sometemento político da propiedade en cuestión a unha fortificación plenamente funcional e con potestade xurisdicional. O sub ou o subtus serían marca de dominación e non referencia xeográfica, e o castrum sería a fortificación á que a propiedade en cuestión estaría vinculada. O mesmo acontecería co caso de mons, ao se considerar un sinónimo pleno de castrum.

A hipótese, que tivo un grande desenvolvemento en Portugal, especialmente de man de C. A. Ferreira de Almeida ${ }^{29}$ nun primeiro momento e de M. Barroca ${ }^{30}$ a día de hoxe, propuña por tanto unha rede de fortificacións altomedievais moi densa, con máis de trescentos castelos entre o Douro e o Miño. Isto falaríanos dun intenso proceso de encastelamento, seguindo o modelo canónico proposto por Toubert para o Lacio ${ }^{31}$ e aplicado posteriormente a outras latitudes europeas, que se desenvolvería no período altomedieval e que na segunda metade do século XI sería abandonado, esquecido e substituído por unha nova rede de castelos moito menos espesa porén con restos máis evidentes, tanto dun punto de vista material como documental. Serían os novos xa cabezas de terra e identificaríanse, dun punto de vista arquitectónico, como castelos románicos.

Os traballos sobre fortificacións destes autores teñen dado resultados fundamentais e aínda hoxe son claves no estudo dos castelos na Península, mais no

\footnotetext{
${ }_{27}$ Por pór un exemplo, en documentos recuperados do tombo de Celanova aparece en 905 a expresión $s u b$ crepidini montium Castro Vemes, en 1025 subtus monte Veimes, en 1067 subtus monte Vemes, e só dous anos máis tarde, en 1069, inter castro Vemes et rivulo Limie, José Miguel AndRADE CERnADAS, O Tombo de Celanova: Estudio introductorio, edición e índices, Santiago de Compostela, Consello da Cultura Galega, 1995, páxs. 161-162, 63-64, 68, 751-752, docs. núm. 101, 34, 38 e 545.

${ }_{28}$ M. Lucas Álvarez, El Tumbo de San Julián..., doc. núm. 147, páx. 309, ano 1080.

${ }^{29}$ Carlos A. Ferreira de AlmeidA, "Castelos medievais no noroeste de Portugal”, en Fernando Acuña Castroviejo (coord.), Finis Terrae: Estudios en lembranza do Pr. Dr. Alberto Balil, Santiago de Compostela, Universidade de Santiago de Compostela, 1992, páxs. 371-385 e Carlos A. Ferreira de AlmEIDA, Castellologia medieval de Entre-Douro-e-Minho. Desde as origens a 1220, trabalho complementar para prestação de provas de doutoramento em História de Arte, Universidade do Porto, inédito, 1978.

${ }^{30}$ Mário Barroca, "Prope litore maris: O sistema defensivo da orla litoral da Diócese do Porto", en Carlos Amaral (coord.), Un Poder entre Poderes. Nos 900 Anos da Restauração da Diócese do Portoe e da Construção do Cabido Portucalense, Porto, Universidade Católica Portuguesa - Cabido Portucalense, 2007, páxs. 197-246 e Mário BArrocA, "Fortificações e povoamento no norte de Portugal”, Portugalia, 25 (2004), páxs. 181-204.

31 Pierre TOUBert, Les structures du Latium médiéval: Le Latium méridional et la Sabine du IXe siècle à la fin du XIIe siècle, 2 vols., Roma, École Française de Rome, 1973.
} 
entanto non todos os puntos das súas propostas teñen sido aceptados con total unanimidade pola comunidade académica. A hipótese concreta que vimos de presentar foi matizada, entre outros, por A. E. Marques, que non cre que este tipo de referências a montes remeta sempre para estruturas fortificadas ${ }^{32}$. Para este autor, subtus ou ad radicem non implican dependencia político-militar, aínda que nalgunhas ocasións puntuais poida darse, senón que traducirían, na maior parte dos casos, unha relación topográfica. Desa maneira, explica:

O facto de estas referências a montes e castros serem frequentemente acompanhadas pela menção a um rio próximo, como já constatámos, será porventura o indicio mais importante de que ambos os elementos eram utilizados pelos escribas em virtude do protagonismo que assumiam na paisagem que os rodeava. Num território com a configuração física do Entre-Doutro-e-Minho, muito acidentado e abundantemente irrigado, seria difícil que assim não fosse $e^{33}$.

No presente caso de estudo debemos posicionarnos consonte a visión de Marques, en tanto que a ausencia de evidencias tanto materiais como documentais, para alén desas sinxelas construcións lingüísticas, non nos permite crer na existencia dunha densa rede de fortificacións altomedievais en uso como a que propoñen Almeida e Barroca nos seus estudos para o norte de Portugal. De feito, se nalgúns casos efectivamente pode haber ambigüidade no uso de monte e castro, noutros a claridade léxica é meridiana. O monte Eribio, que hoxe mantén o topónimo evolucionado en Oribio $^{34}$, aparece entre os anos 854 e 1120 en 46 documentos do tombo de Samos, en 28 deles como alpe e en 13 como monte, para alén de dúas ocasións en que se usan eses dous substantivos alternativamente no mesmo diploma e outros tres textos en que aparece o topónimo sen estar acompañado de ningún substantivo común ${ }^{35}$. En 27 destes documentos acompañado de $s u b$ e en

\footnotetext{
32 André Evangelista Marques, O casal. Uma unidade de organização social do espaço no Entre-Douro -e-Lima (906-1200), Noia, Toxosoutos, 2008, páx. 149.

33 A. E. Marques, O casal..., páxs. 149-150.

${ }^{34}$ Frei Martín Sarmiento, na súa viaxe a Galiza do ano 1745, recolle ambas as formas e insiste na importancia simbólica do monte do punto de vista da paisaxe, primeiro en relación ao propio mosteiro de Samos e a continuación ao mencionar unha tradición popular segundo a cal do punto máis alto do Oribio se vía o Pico Sacro, na entrada da cidade de Compostela: "Pásase río que viene de la izquierda antes de Tira Castelae, y se junta cerca con el río Sarria, que baja del Oribio o Eribio, y se llama Pena Soa, y es el pico que se ve desde la Altamira en el cercado de Samos y dicen que de él se ve el Pico Sagro. Pasantes”, Fr. Martín SARmiento, Viaje a Galicia (ed. José Luís Pensado, 1975), Salamanca, Universidad de Salamanca, 1745, páx. 167.

35 Todos os documentos están recolleitos no tombo de Samos editado por M. LuCAs Álvarez, El Tumbo de San Julián... A listaxe completa será incluída na nosa tese de doutoramento en marcha. A data do documento de 854 que incluímos como máis antigo é, como nos explica o mesmo LuCAs Álvarez, El Tumbo de San
} 
14 de subtus, habendo certa preferencia polas combinacións sub alpis e subtus monte ${ }^{36}$, mais sen ser a correspondencia total, e rexistrándose unha mención tamén do tipo ad radicem. Só catro documentos utilizan expresións que fican fóra do esquema que estamos a analizar: un per terminos de, un non procul a e dous discurrente de. Ademais, na práctica totalidade das ocasións aparece efectivamente acompañado dun río e nun bo número delas tamén dun territorio. Dun punto de vista lingüístico, por tanto, o encaixe deste monte no marco da teoría proposta por Almeida é absoluto, e estaríamos entón ante un castro en uso amplamente documentado. E no entanto nunca en todo o noso corpus diplomático recibe o nome de castro nin outro similar que implique de maneira literal a existencia dunha fortificación.

O Oribio aparece con tanta insistencia porque é usado na maior parte dos casos como referente para presentar propio o mosteiro de Samos, acompañado case inequivocamente do río Sarria e, en boa parte dos casos, indicando que se encontra en territorio Gallecie. Isto poríanos nunha situación un bocado particular, porque non se trataría xa só de asumir que unha pequena propiedade está vinculada a un castro reutilizado desde o que se exerce o poder, senón que un dos principais mosteiros galegos da época, que ostenta un couto xurisdicional propio e posúe numerosas propiedades, sería política e militarmente dependente dun castelo, do que á súa vez non ficaron restos e do que nada se di na abondosa documentación producida polo propio mosteiro, á parte das ditas mencións sub alpe. Se lle incluímos, por acaso, que a suposta fortificación sería promovida polas comunidades locais ${ }^{37} \mathrm{e}$ non pola monarquía ou as altas elites, fica un panorama realmente pouco verosímil coas evidencias de que dispomos actualmente. Achamos por tanto que a resposta ten de ser a máis sinxela e que en efecto, como os redactores dos documentos sabían e a arqueoloxía e a toponimia parecen confirmar, non debe ter habido no alto ningunha fortificación relevante, nin en uso nin en ruínas visíbeis, e por iso é que non houbo tampouco dúbida ningunha á hora da escolla dos termos para nomealo. Cos seus case 1.500 metros no punto máis alto, o Oribio menciónase porque é o horizonte serrán, a bacía visual, o referente máis claro.

A maneira de explicar entón aqueles casos en que o uso dos termos castro e monte se aplica de maneira indistinta pasa por asumir que a súa mención ten como única intención resaltar a situación de determinado emprazamento en relación a

\footnotetext{
Julián..., doc. núm. 99, páx. 238, é cuestionada por algúns autores, mais o editor dá ese ano por válido e así o recollemos. De se optar por consideralo un texto máis tardío, a primeira vez que aparecería sería no ano 872, M. Lucas Álvarez, El Tumbo de San Julián..., doc. núm. 5, páx. 69.

${ }^{36}$ Se cadra insinuando que a escolla entre $s u b$ ou subtus en contextos semellantes está determinada pola palabra a seguir, e concretamente polo facto de esta comezar por vogal ou consoante.

${ }^{37}$ M. Barroca, "Fortificações e povoamento...”, páxs. 189-191 e C. A. F. de Almeida, Castellologia medieval..., páxs. 6-8.
} 
un lugar de altura. Non parece disparatado pensar que cando os redactores dos textos tiñan que explicar que unha villa ${ }^{38}$ estaba ao pé dun outeiro, e no alto dese outeiro había un castro, poderían escribir que a vila estaba ao pé do outeiro ou ao pé do castro, sen iso supor que outeiro sexa un sinónimo absoluto de castro. Por outra banda, se a preposición subtus é frecuente acompañando ditos termos é porque, efectivamente, a maior parte dos núcleos campesiños se encontran en vales e chairas por baixo dos montes que ocupan boa parte da nosa xeografía; de haber en cada un deles unha fortificación en uso encontrariámonos ante unha rede castral altomedieval compactísima, a un nivel inédito en calquera outro punto da Europa, que por tanto debería ter deixado probas moito máis sólidas e numerosas da súa propia existencia.

Achamos que só baixo estas claves é que debemos interpretar mencións tan ilustrativas como basilica fundata esse dinoscitur loco predicto Samanos, ripa fluvii Sarrie, subtus alpe Eribio, prope monte et castro que dicitur Omer ${ }^{39}$. Tense proposto que esta racionalización do espazo ten a súa orixe nunha ocupación do terreo pouco densa: ao non estar o agro definitivamente fixado nin a diferenciación entre espazos cultos e incultos aínda clara non se precisan límites artificiais precisos senón grandes marcas naturais que definan as áreas dunha maneira ampla ${ }^{40}$. Non é descoñecido que, coa intensificación da explotación agrícola nos séculos plenomedievais as marcas vanse clarificando e vólvense máis precisas e ríxidas. No entanto, xa en período altomedieval encontramos textos en que as descricións son tan detalladas e os lindes tan claros, cando é necesario, que talvez o uso de montes, ríos e castros como principal identificador dunha propiedade non teña tanto a ver cos límites e a súa maior ou menor precisión, senón coa busca de referentes facilmente recoñecíbeis por todo o mundo coa lectura do documento. O fin non é outro que localizar con rapidez e sen posibilidade de dúbida a propiedade que se está a doar ou vender.

Así, a función referencial á hora de concibir a paisaxe tórnase, sen dúbidas, das máis visíbeis a través dos diplomas. Ora ben, non debemos perder de vista que isto ten a ver sobre todo coa natureza das fontes, e se callar non tanto co conxunto da sociedade: describir o territorio é imprescindíbel nunha documentación que tenta garantir o dominio dunha determinada institución sobre o mesmo. O que por acaso si podemos concluír é que, posto que a validez dos documentos escri-

\footnotetext{
${ }_{38} \mathrm{O}$ termo villa ten uns matices específicos que se aplican aos asentamentos campesiños altomedievais, como adiantamos en páxinas anteriores. No entanto, para non abusarmos do termo latino innecesariamente, recorreremos en ocasións á súa evolución galega "vila", advertindo desde xa que o seu significado é o de 'villa' e en ningún caso o de 'núcleo urbano de mediana entidade' co que sobrevive no galego actual.

${ }^{39}$ M. Lucas Álvarez, El Tumbo de San Julián..., doc. núm. 135, páx. 294, ano 1120.

${ }^{40}$ Ermelindo Portela Silva, "La articulación de la sociedad feudal en Galicia", en En torno al feudalismo hispanico: I Congreso de Estudios Medievales, León, Fundación Sánchez-Albornoz, 1087, páxs. 334-336.
} 
tos esixía consenso social e que os castros aparecen continuamente ao longo do corpo diplomático, a súa relevancia na construción mental da paisaxe medieval galega é de primeiro nivel.

\section{O CASTRO COMO LÍMITE TERRITORIAL}

Talvez con isto teña a ver o facto de que ao longo do proceso plurisecular de ocupación dos vales e abandono dos asentamentos en altura, do desencastelamento, estes locais non só non ficaran esquecidos senón que pasaran a ocupar posicións relevantes como marcos na nova ordenación do territorio. Os castros deixaron de ser o centro das comunidades humanas e convertéronse na periferia ${ }^{41}$, porén nunha periferia significada, relevante no imaxinario colectivo e funcional como fito delimitador á hora de dividir, e por tanto de conceptualizar o territorio. Vexamos un exemplo concreto. En 1037 é doada ao mosteiro de Samos unha pequena villa do val do Sarria, Villare, que identificamos coa aldea de Viládiga, na actual parroquia de San Martiño de Río, concello de Láncara. Non encontraremos aquí, nin noutro documento medieval, a medida exacta dunha superficie de terra; a imprecisión, a aproximación, ou a valoración dunha unidade pola súa produción e características e non polo seu tamaño son as maneiras ordinarias de as describir. Mais, novamente, isto non debe orientarnos cara á asunción dunha cativa ocupación do espazo ou cara á falta de coñecemento das dimensións reais que se xestionaban. Outramente, os termos de Viládiga están claros e o que se denota en última instancia é xusto esa ausencia de oposición radical entre as persoas e a contorna ${ }^{42}$, un coñecemento detido que integra os elementos humanos e os naturais creando unha paisaxe que nese sentido non é binaria. A delimitación que se nos ofrece de Viládiga permítenos coñecer os seus termos con claridade e detalle. Vexamos:

Et est ipsa villa per suos terminos antiquos: per terminos de Loserio, et inde per termino de sancto Petro, et per termino de Corveli, et inde per rio et inde per castro Micerani et per castro super Toldanos ${ }^{43}$.

Os termos da vila, que se reafirman como antigos, pasarían por Louseiro, San Pedro, Corvelle, Río, o castro de Meixarín e o castro sobre Toldaos. De maneira

\footnotetext{
${ }_{41}$ José Carlos SÁnchez PARdo, Territorio y poblamiento en Galicia entre la Antigüedad y la plena Edad Media, Santiago de Compostela, Servizo de Publicacións da Universidade de Santiago de Compostela, 2008, tese de doutoramento publicada en CD, páx. 555.

42 Arón Gurievitch, As Categorias da Cultura Medieval, Lisboa, Caminho, 1991, páxs. 74-75.

${ }^{43}$ M. Lucas Álvarez, El Tumbo de San Julián..., doc. núm. 205, páx. 384, ano 1037.
} 


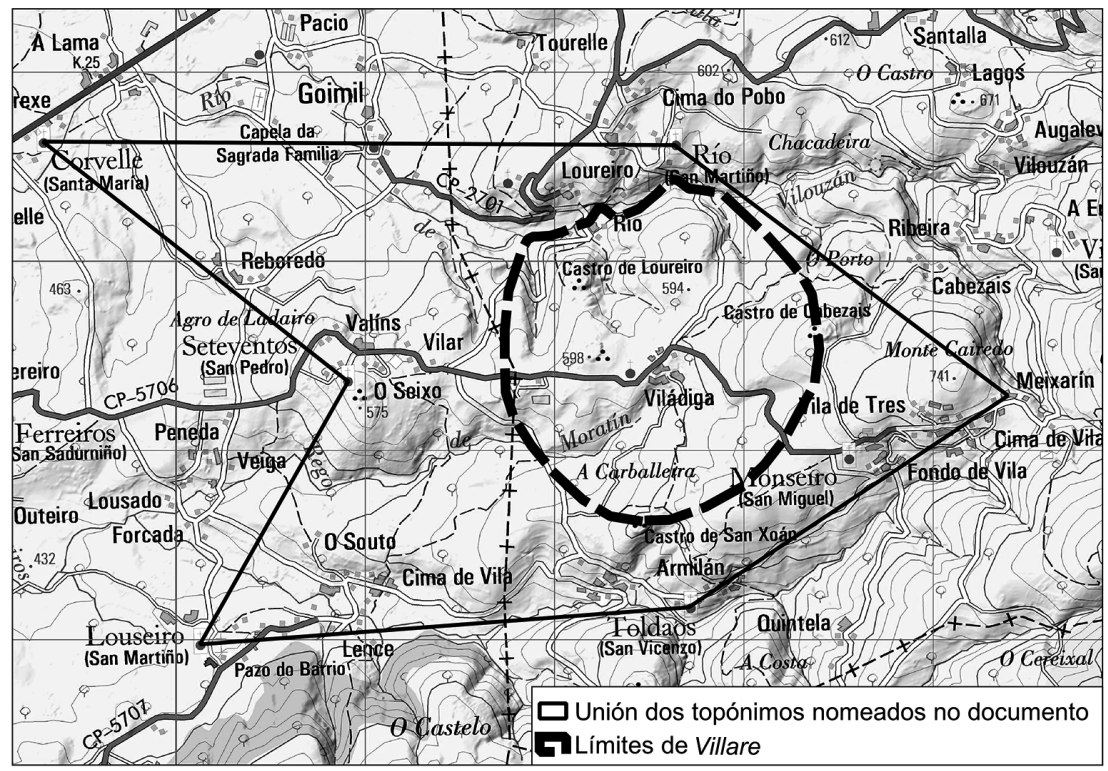

Fig. 1. Límites do lugar de Villare (Viládiga) en 1037 (doc. 205 do Tombo de Samos). Mapa base: MTN50-0124

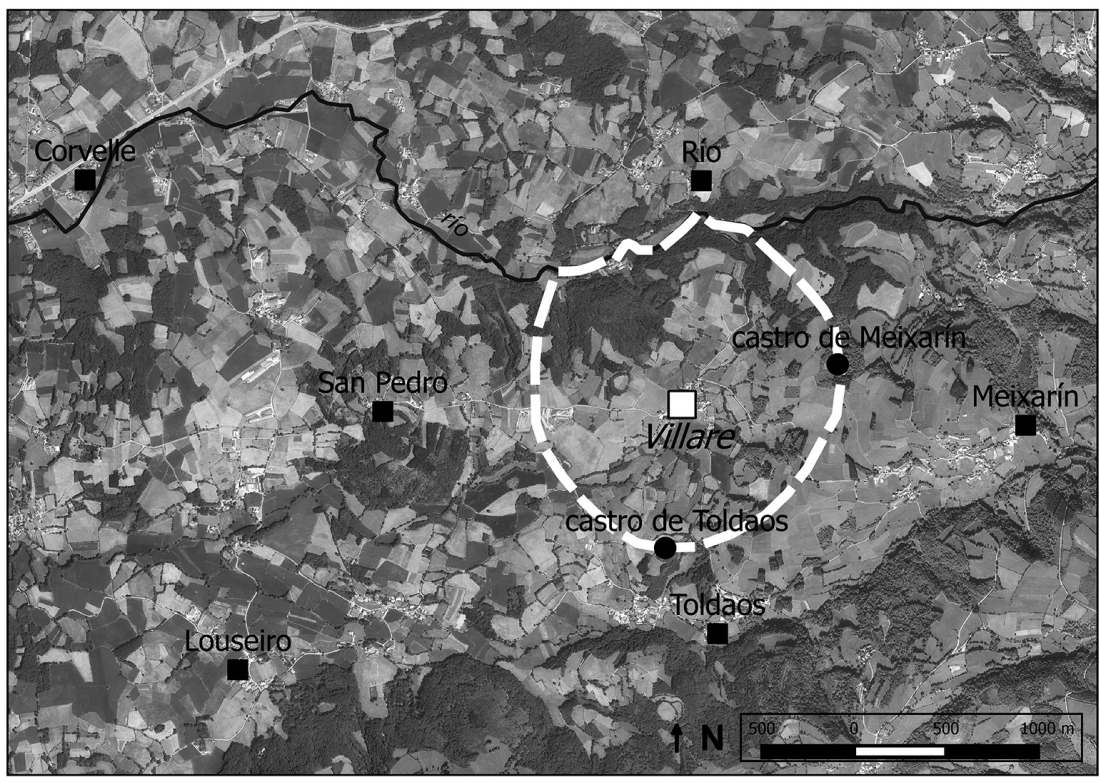

Fig. 2. Villare (Viládiga) en 1037 segundo o doc. 205 do Tombo de Samos. Mapa base: ortofoto PNOA-124 (2015) 
aproximada, podemos reconstruír o recorrido que se describe localizando os lugares sobre o mapa 1:50.000 do IGN, tal como se ve na Figura 1. Para chegarmos das liñas rectas e continuas, en que simplemente unimos os topónimos actuais ${ }^{44}$, até a xeometría de liñas discontinuas máis grosas, que é a nosa proposta dos límites de Villare, temos de ter en conta unha serie de consideracións.

A primeira, seguindo a García de Cortázar, que todas as unidades de ordenación do espazo teñen un centro, unha periferia e unha fronteira, e que ademais poden ser tanto físicos como mentais, ou ambas cousas dunha vez ${ }^{45}$. Cando no diploma se di que a división vai per terminos de Loserio, et inde per termino de sancto Petro, et per termino de Corveli déixase claro que Viládiga non chega até os núcleos desas outras entidades, senón até os seus terminos, isto é, até os seus estremos. Entre o centro de Viládiga e os de Louseiro, San Pedro e Corvelle existen respectivas periferias que nalgún punto fan fronteira. Nestes casos non se dá ningunha referencia concreta para detectar este punto de encontro, que non obstante sería recoñecido sen problemas por calquera das persoas implicadas na doazón.

Si se explicita, por contra, que ao norte, leste e sur esas fronteiras pasan exactamente polo río, polo castro Meixarín e polo castro que está por riba de Toldaos, non recorrendo nesta ocasión ao contacto con outras vilas senón a realidades materiais que funcionan como fitos de ordenación territorial, que conforman coa súa presenza física o punto estrito das fronteiras. $\mathrm{O}$ río, con certeza sempre clave na aprehensión humana no territorio e tanto máis na Idade Media, dá nome ademais a un núcleo de poboación, hoxe San Martiño de Río, de maneira que non se pode descartar que a mención do texto refira talvez a este lugar e non ao propio regato. De facto o máis plausíbel de se referir ao río como accidente xeográfico sería que se usase un dos termos latinos frecuentes, por acaso rivulum, mais co uso do romance rio a ambigüidade é maior. Sexa como for, e ao se encontrar a igrexa de Río á outra beira do regato, parece de todo probábel que ese miúdo curso de auga acoutase o espazo da nosa vila polo norte ${ }^{46}$. Ao final estas descricións procuran a simplicidade, e dificilmente algo máis sinxelo que chamarlle rio ao río.

\footnotetext{
$\overline{44}$ Tomamos, nos catro casos en que é posíbel, a igrexa parroquial como punto de referencia, seguindo a García de Cortázar e a súa afirmación de que cada "parroquia, ya fuera mononuclear o plurinuclear, tenía, igualmente, su centro en el templo y, desde allí, se extendía hasta la linde, la frontera con otras parroquias". J. Ángel García de CoRTÁzAR, "Organización del espacio, organización del poder entre el Cantábrico y el Duero en los siglos VIII a XIII”, en J. Ángel García de Cortázar (ed.), Del Cantábrico al Duero. Trece estudios sobre la organización social del espacio en los siglos VIII al XIII, Santander, Universidad de Cantabria, 1999, páx. 25.

45 J. Á. GARCía de CoRTÁzar, "Organización del espacio...”, páx. 25.

${ }^{46}$ Unha outra opción que nun primeiro momento temos barallado sería que, posto que o núcleo de poboación principal de Río non está arredor da igrexa senón precisamente pegado ao río, a fronteira entre os dous lugares non pasara exactamente por aí senón por un lugar intermedio entre esta aglomeración e a de Viládiga. Unha proposta de límite podería ser, se cadra, o castro de Loureiro, que tamén é coñecido
} 
Se a identificación do regacho parece transparente como as súas escasas augas, non é tan sinxelo no caso dos castros. Como xa temos dito, a densidade deste tipo de xacementos impresiona. Se ollamos no fragmento de mapa 1:50.000 que vimos de utilizar como base da Figura 1 veremos que ademais dos dous castros polos que pasa o lindeiro de Viládiga están cartografados dous máis, dentro do espazo da vila, outros dous, fóra, máis os dous sobre os que se encontran as igrexas de San Pedro de Seteventos ${ }^{47}$ e San Martiño de Río e aínda outros dous en Corvelle e Goimil que non están representados no mapa porén que si localizamos no rexistro arqueolóxico da Xunta ${ }^{48}$. Dez castros nunha área de arredor de $15 \mathrm{~km}^{2}$; a identificación dos enclaves non é algo que poida facerse nesta ocasión sen un traballo previo de reflexión.

Tanto é así que se procuramos super Toldanos, sobre Toldaos, non hai un só castro, senón dous. Este lugar, que ao igual que o seu homónimo Toldaos do Incio provén do étimo toletanus ${ }^{49}$ no seu plural, remitindo á inmigración desde Toledo após a islamización da Península ${ }^{50}$, encóntrase nun enxoito val polo que discorre un regato chamado hoxe de Quintela. Ás dúas beiras hai cadanseu outeiro co seu respectivo castro, cartografados como Castro de San Xoán e Castro de Mouro. A igrexa de Toldaos, que non se encontra no núcleo do mesmo nome senón un bocadiño apartada, equidista de ambos enclaves; ademais, o de Mouro, está a unha altitude maior que o de San Xoán, de maneira que é predominante dun punto de vista paisaxístico. Mais a pesar diso inclinámonos a supor que o documento nos está a falar do primeiro. Un indicio é que tanto a igrexa como a aldea de Toldaos se encontran na súa beira do río, e por tanto na aba da súa cuíña; visto in situ, o vínculo parece claro. Mais a clave é que o punto en que Toldaos e Vilar lindan ten de estar necesariamente entre Toldaos e Vilar. Se se tratase do

\footnotetext{
como castro de Río, funcionando a norte da mesma maneira que os seus homólogos a sur e leste. Mais non parece que esta hipótese deba primarse. Se temos en conta a precisión do documento, non tería sentido que se indicasen literalmente como límites dous castros e para referir a un terceiro se fixese de maneira indirecta a través do termo rio, que de maneira ningunha permite especificar se se trata da fortificación, do curso de auga ou en xeral doutro punto vinculado coa entidade que recibiu ese topónimo.

${ }^{47} \mathrm{O}$ inventario da Xunta especifica que a igrexa está construída sobre o segundo recinto do castro, Inventario do Patrimonio Arqueolóxico de Galicia...

48 Inventario do Patrimonio Arqueolóxico de Galicia...

49 Ana Boullón Agrelo, Antroponimia medieval galega (ss. VIII-XIII), Tubingen, Niemeyer, 1999, páx. 432.

${ }^{50} \mathrm{C}$. Baliñas tense detido na importancia dos continxentes poboacionais chegados de Al-Ándalus nesta área, que tería como a súa principal consecuencia o restabelecemento do mosteiro de Samos na metade do século IX. Sería, no entanto, unha presenza relevante só dun punto de vista cualitativo, ao ser a poboación autóctona sempre predominante: "as distintas afluencias de poboación foránea que chegan á Galicia nuclear no decorrer dos séculos VIII e IX teñen unha moi cativa importancia numérica e non provocan mudanzas de consideración na composición previa da poboación galaica", Carlos Baliñas Pérez, Do Mito á Realidade. A Definición Social e Territorial de Galicia na Alta Idade Media (Séculos VIII e IX), Santiago de Compostela, Fundación Universitaria de Cultura, 1992, páx. 190.
} 
castro que coroa o lugar polo sur, o propio Toldaos ficaría dentro dos límites de Vilar e a delimitación non faría sentido.

Pola súa parte, a evolución do latín Micerani ao galego Meixarín é a menos evidente dos nomes cantos aparecen na listaxe, mais non é imposíbel. Ares Vázquez, na súa análise da toponimia do veciño concello de Triacastela, encóntralle un símil a esta mención co topónimo Meizarán ${ }^{51}$, que identifica co lugar mencionado na Divisio Theodomiri na segunda metade do século VI como Meicerani ${ }^{52}$. Este núcleo dista só dez quilómetros da área de que estamos a falar e, segundo o autor, é posíbel que ambos termos procedan dun antropónimo, aínda que non achou documentos que o corroboren. Para alén disto, o feito de se tratar dun nome tan inusual ${ }^{53}$ e de se encontrar no lugar exacto para que a enumeración dos termos sexa completa e coherente, fai que non teñamos dúbidas na identificación. A respecto da localización do castro, a lóxica é a mesma que a de Toldaos: o fito que se use para marcar os lindes de Viládiga debe estar necesariamente entre Vilar e a entidade en cuestión. Exactamente entre Meixarín e Viládiga encontramos o castro que na cartografía aparece como Castro de Cabezais. Aí a solución.

Detectados os límites, o que se nos descobre dentro deles, no centro xeométrico do círculo imperfecto que se foi delimitando, é a actual aldea de Viládiga. Aínda que pertencente hoxe á parroquia de Río, arredor dela fan fronteira as de Monseiro, Toldaos, Louseiro e Seteventos, así como os concellos de Láncara e Sarria, aos que pertencen as dúas primeiras e as dúas últimas respectivamente. O feito de se tratar dun hábitat único, aglomerado, cun número considerábel de construcións, cun castro na súa contorna e cunha capela a San Roque, da que descoñecemos a cronoloxía, fai pensar en que efectivamente nalgún momento foi unha vila de certa entidade e que só co paso do tempo ficaría anexada a Río. Así o parece corroborar un documento do ano 1111 en que Viládiga, de nome aínda Vilar, e Río aparecen como entidades diferenciadas na descrición dos límites de Pendurados, unha vila que non fomos quen de identificar: per terminos de Vilar et per terminos de sancto Martino de Rio et per terminos de Maurilion usque in terminos de Corveli per ubi illa potueritis invenire ${ }^{54}$. A claridade da documentación e da paisaxe é tal que a inconsistencia lingüística da evolución de Villare

\footnotetext{
${ }^{51}$ Nicandro Ares VÁzQuez, "Toponimia do concello de Triacastela", Lvcensia. Miscelánea de Cultura e Investigación, 47 (2013), vol. XXIII, 297-306.

52 José Luís López Sangil e José Manuel Vidán Torreira, “Tumbo Viejo de Lugo (Transcripción completa)”, Estudios Mindonienses. Anuario de estudios histórico-teológicos de la Diócesis de Mondoñedo-Ferrol, 27 (2011), páx. 44, doc. 6, ano 572.

53 En toda a documentación latina galega só encontramos esta mención a Micerani e rexístrase só unha vez como Meixarín en toda Galiza actual. Buscador de Topónimos - Toponimia de Galicia, Xunta de Galicia. [Consultado online en http://toponimia.xunta.es/gl/Buscador (18/04/2017)].

${ }^{54}$ M. Lucas Álvarez, El Tumbo de San Julián..., doc. núm. 13, páx. 88, ano 1111.
} 
en Viládiga e non en Vilar ${ }^{55}$ é case anecdótica e podería explicarse por múltiplas razóns, ningunha delas extraordinaria. De facto, nin sequera teríamos por que estar ante unha mudanza de topónimo, sendo posíbel a simple evolución lingüística en base á incorporación dalgún sufixo ou termo complementario ao Villare orixinal.

Vimos falando até agora da construción social da paisaxe, mais até o momento aínda non insistimos no facto de que a sociedade, tamén a medieval, non é en absoluto homoxénea. A visión do mundo dun aristócrata, como estudou Pallares na súa biografía de Ilduara Eriz ${ }^{56}$, tiña de ser por norma máis ampla do que a dun campesiño: as viaxes, as lecturas, os obxectos de valor chegados de lonxe e o contacto con nobres doutras latitudes axudan a estender os marcos da representación do territorio. No entanto, até onde a documentación mostra, os castros continúan a manter o seu papel ordenador sexa cal for a escala territorial ou a xerarquía das persoas implicadas no acordo que se estabeleza en cada caso.

Con data de 997, un diploma de autenticidade dubidosa porén de grande riqueza informativa recolle a doazón da villa de Saa por parte do rei Bermudo II ao mosteiro de Samos. A polisemia da palabra, por acaso, non pode enganarnos, non é esta vila unha pequena explotación campesiña ao uso; estamos ante algo maior. Saa é vinculada coa monarquía desde o tempo de Ramiro I, linda e probabelmente ten algún tipo de relación co tamén especial espazo da regali villa de Larín, onde se celebraron repetidas asembleas xudiciais altomedievais ${ }^{57}$, e o máis importante, inclúe como adiunctiones súas unha boa listaxe de lugares cuxa identificación nos permite presumir que se trataba dunha área nada desprezábel.

Independentemente de o documento se basear nun dato auténtico ou non, a descrición dos marcos de Saa é altamente interesante:

concedo ibi illam per suis terminis et locis antiquis, id sunt: per terminos de Elarin et per illam mamolam de super Ruvin, et inde sub sancta Marta et inde ad Matacanes; et de alia parte per illa canal de sub castro et inde per aquam rugitoriam et inde ad illum vallum qui est inter Vilar Sentan et Sala et inde ad Lamas usque ad pennam superpositam ${ }^{58}$.

\footnotetext{
55 Debemos apuntar que existe un lugar non lonxe de alí que a día de hoxe si mantén o topónimo de Vilar, porén trátase dunha pequena aglomeración mesmo ao pé do castro de Seteventos case en solución de continuidade coa aldea de Seteventos e a súa igrexa, de maneira que ningún dos outros elementos de identificación coincidirían. Concretamente, o feito de que no documento que vimos de analizar detidamente Villare se delimite per termino de sancto Petro fai imposíbel que se trate deste lugar, que se encontra precisamente en San Pedro, a pouco máis de 100 metros do templo.

${ }^{56} \mathrm{M}^{\mathrm{a}}$ del Carmen Pallares Méndez, Ilduara, una aristócrata del siglo X, Sada, Ediciós do Castro, 2004 ( $2^{\mathrm{a}}$ ed. rev. e ampl.).

57 José Miguel Andrade Cernadas, "Villas regias y asembleas judiciales entre los siglos X y XI: el caso de Larín”, Revista Signum, 12 (2011), II, páxs. 18-35.

${ }^{58}$ M. Lucas Álvarez, El Tumbo de San Julián..., doc. núm. 6, páx. 73, ano 997.
} 
Xa temos mencionado algún estudo que mostra como os castros funcionaban como escenario principal das representacións da mitoloxía popular galega, mais o que non se dixo até o momento é que ese papel compárteno, efectivamente, cos megálitos. Antas e pedrafitas, que como os castros chegaron até a contemporaneidade fortemente significadas, compartían con eles na Idade Media unha función demarcadora. Con certeza a mámoa de sobre Rubín e, posibelmente, tamén a pennam superpositam ${ }^{59}$ dan proba diso. Por acaso, talvez o topónimo que chegou aos nosos días nomeando o pequeno núcleo de poboación de Pedra de Saa, na parroquia lancará de Armeá, teña algo a ver con esa pena sobreposta.

A escolla de megálitos non parece ser unha nova ocorrencia desta altura. Podémola rastrexar até o momento máis antigo do que a documentación nos permite coñecer, pois xa no Parroquial Suevo, documento que recolle os acordos aos que se chegou no concilio de Lugo celebrado en 569 baixo o reinado de Teodomiro e que aínda que interpolado é considerado un texto fidedigno ${ }^{60}$, explícase que os bispados e igrexas demarcábanse da seguinte maneira: per riuulorum cacuminaque montium seu antiquorum castrorum uel archarum confinia ${ }^{61}$. Os antiquorum castrorum son os vellos castros ${ }^{62}$, novamente equiparados aos montes para funcionaren como fitos, e as archarum confinia son as pedras fincadas a faceren de límites ${ }^{63}$, en ocasións antiquísimas construcións megalíticas. Nada novo baixo o sol. Non estamos por tanto ante un costume do campesiño que remite a aqueles accidentes

\footnotetext{
${ }^{59}$ Podería ter sido tamén un marco de orixe medieval ou mesmo algún elemento doutro tipo e cronoloxía, por exemplo unha rocha natural esculpida polas inclemencias meteorolóxicas ou até un miliario.

${ }^{60}$ A. Isla Frez propón que o documento tería sido redactado entre os anos 572 e 580, Amancio IsLa Frez, La sociedad gallega en la Alta Edad Media, Madrid, Consejo Superior de Investigaciones Científicas (CSIC), 1992, páxs. 10-16.

61 J. L. López SAngil e J. M. Vidán Torreira, “Tumbo Viejo de Lugo...”, páx. 42, doc. 6, ano 572.

${ }^{62}$ Esta interpretación xa ten sido apuntada por Ferro Couselo: Los castillos a que aqui se alude son seguramente antiguos oppida o civitates, que con el nombre de cidade se encuentran con frecuencia en demarcaciones posteriores, cita tomada de Carlos Andrés GonzÁLez PAZ, “ 'Castrum et castellum': algunos ejemplos del marco altomedieval gallego”, en Amador Ruibal Rodríguez (coord.), Actas del III Congreso de Castellología Ibérica: 28 de octubre - 1 de noviembre, Guadalajara, Asociación Española de Amigos de los Castillos - Diputación de Guadalajara, 2005, páx. 112.

${ }^{63}$ No territorio ibérico noroccidental o termo latino medieval archa é polisémico, pois significa a un tempo "mojón de delimitación de las propiedades; señal divisoria o delimitativa de las propiedades" e "cofre, caja, arca", Maurilio Pérez GonzÁlez, Léxico Latinitatis Medii Aevis Regni Legionis (s. VIII-1230), Turnhout, Brepols Publishers, 2010, páxs. 67-68. Desta maneira pode referir ben a un "elemento de delimitação" en xeral, ben a "sepulturas megalíticas" André Evangelista MARQues, Da representação documental à materialidade do espaço. Território da diocese de Braga (séulos IX-XI), Porto, CITCEM - Afrontamento, 2014, páxs. 318-320. A converxencia resulta especialmente interesante tendo en conta que, como vimos, as construcións megalíticas efectivamente tamén funcionaban desde antigo como delimitadores. Só como apuntamento, a palabra latina clásica de que deriva, arca, coincide co ablativo feminino de arx / arcis, que significa entre outras cousas 'castelo', 'cidadela', 'lugar de altura' ou 'refuxio', o que insiste na multiplicidade dos posíbeis matices, aínda que para o caso da documentación galega medieval esta última hipótese sexa pouco verosímil.
} 
que dan forma aos seus terreos de labranza: os castros son tan importantes do punto de vista simbólico que os reis escóllenos como marcas delimitadoras dos espazos que van ceder en xurisdición aos seus vasalos.

Máis de catro séculos despois da morte do rei suevo Teodomiro, en 993, Ramiro II confírmalle ao mosteiro de Samos as concesións feitas polos seus antepasados e fixa o couto do mosteiro indicando o percorrido por unha serie de fitos que marcan o límite, incluíndo et inde alia Petra Ficta sub Calvor e et inde per castro Saliceto ${ }^{64}$. En 1146, en pleno feudalismo, Afonso VII ampliou ese couto per illo castro de Sirgarios ${ }^{65}$. É obvio que moito ten mudado, en case calquera aspecto, entre os tempos de Teodomiro, Ramiro II e Afonso VII. No entanto, a conceptualización do territorio que transmiten os documentos parece suxerir que a implantación dos sucesivos poderes non substitúe, nin apenas modifica, a rede anterior $^{66}$. O que fai é controlala, e para conseguilo non dubida en utilizar con recorrencia aqueles lugares de memoria ${ }^{67}$ e a súa carga simbólica acumulada.

\section{O CASTRO COMO ESPAZO RELIXIOSO}

Se para a imposición de novos poderes políticos se aproveitaron as condicións previas, nomeadamente o simbolismo dos locais de memoria e as vellas redes de organización territorial, a Igrexa Católica, exitosa ao longo dos séculos en boa medida precisamente pola súa capacidade de sincretismo e adaptación, non deixou pasar esa oportunidade de ouro. López Quiroga sinala como no I Concilio de Toledo, que tería lugar entre os anos 397-400, faise mención aos castelli como un dos locais en que é posíbel que encontrar unha igrexa ${ }^{68}$. Pola súa banda Martín Viso fai notar que no mapa eclesiástico que se perfila no Parroquial Suevo, na segunda metade do século VI, figuran como parroquias ${ }^{69}$ topónimos

\footnotetext{
${ }_{64}$ M. Lucas Álvarez, El Tumbo de San Julián..., doc. núm. 40, páx. 134, ano 993.

${ }^{65}$ M. Lucas Álvarez, El Tumbo de San Julián..., doc. núm. 57, páx. 169, ano 1146.

${ }^{66}$ Desde finais do século IX até finais do XI ten lugar un proceso de reorganización do territorio que segundo C. Baliñas se dá en base ao obxectivo da "monarquía galaico-leonesa e dos seus axentes nobres e eclesiásticos" da "creación ex novo dunha rede administrativa de control e explotación do espazo". No entanto, "nun $70 \%$ dos casos dos que existen testemuños, a nova circunscrición administrativa segue as divisorias dos territoria preexistentes, e en máis dun 50\% dos casos, a identidade entre comarca natural e comarca política é total", Carlos BALIÑAs Pérez, "As orixes altomedievais da Terra e Condado de Lemos", en Anselmo López Carreira (ed.), O Condado de Lemos na Idade Media. I Simposio de Historia en Terra de Lemos, Santiago de Compostela, Xunta de Galicia, 2008, páx. 21.

${ }^{67}$ Para afondar neste concepto ver Pierre Nora (ed.), Les lieux de mémoire, vols. I, II (t. 1-3), II (t. 1-3), Paris, Gallimard, 1984-1992.

68 J. López Quiroga, El final de la Antigüedad..., páx. 233.

${ }^{69}$ Como é sabido, as parroquias das que fala este documento non se corresponden co modelo de parroquia creado na plenitude medieval que chegou aos nosos días. Son demarcacións moito máis amplas que, conceptualmente, poderían talvez ter máis a ver cos posteriores arciprestados.
} 
correspondentes con castros de ocupación tardoantiga ou xermánica, que por tanto mantiveron o seu papel como principais eixos do territorio ${ }^{70}$. Quintía Pereira, no seu premiado ensaio que reflexiona sobre as orixes do culto a Santa Mariña como unha posíbel cristianización da deusa Nabia, detecta que as ermidas desa advocación se teñen erguido de maneira estratéxica sobre castros para apropiarse simbólica e ideoloxicamente deses espazos culturais que pertencían ao mundo da mourindade ou que eran lugares de encantamentos, morada de seres temibles ou agocho de tesouros ${ }^{71}$.

A respecto de Samos, o máis antigo de todos os documentos do tombo, con data de 785 e considerado válido polo editor, xa nos fala da apropiación cristiá dun castro, neste caso coa fundación do mosteiro de Calvor sobre-super- o lugar que levaba por nome Castro Astorica ${ }^{72}$. A supervivencia do nome prerromano do castro convive coa existencia dunha vila xa romance aos pés, villa Calvaria, o que nos fala de novo das transformacións fluídas e da ausencia de ruptura ${ }^{73}$. Esta mención é a máis antiga que conservamos, porén non a única. O espazo dos castros foi escolleito para fundacións monásticas, como neste caso, mais tamén para se ergueren pequenas ermidas ou igrexas, que nalgunhas ocasións se acabarían estabelecendo como templos parroquiais. Ao longo da documentación aparecen diversas referencias de carácter relixioso vinculadas con castros, como poden ser Castrum de Sancto Felice ${ }^{74}$ ou Sancto Petro Castro ${ }^{75}$, ademais de mencións a igrexas que sabemos construídas sobre castros aínda que nos textos non se explicite ese aspecto $^{76}$.

Debruzarémonos apenas en dúas. En 982 aparece mencionado o castro de Sancto Vereximo, na doazón que un confeso de nome Lucito Lucídiz lle fai a Samos do mosteiro de San Salvador de Bande e os seus coutos ${ }^{77}$. Entre os territorios que se inclúen no acordo está unha portione que se encontra entre o dito castro e o río Neira. Noutro documento do mesmo ano e sobre as propiedades do mesmo mosteiro, volta aparecer Sancto Vereximo, porén nesta ocasión sen se mencionar a súa natureza castral, nin de ningún outro tipo ${ }^{78}$. A partir de aí, temos que esperar

\footnotetext{
${ }^{70}$ Iñaki Martín Viso, Poblamiento y estructuras sociales en el norte de la Península Ibérica (siglos VI-XIII), Salamanca, Universidad de Salamanca, 2000, páx. 54.

${ }^{71}$ Rafael Quintía Pereira, Mariña: de deusa a santa. A advocación de Santa Mariña na cristianización da Gallaecia, Vigo, Galaxia, 2017, páx. 161.

72 M. Lucas Álvarez, El Tumbo de San Julián..., doc. núm. 137, páx. 298, ano 785.

73 En J. López Quiroga e M. Rodríguez Lovelle, “Castros y castella tutiora...”, páx. 362, faise mención á aparición de cerámica sigillata tardía e en T. RodRíGuez FERnÁndez, "El fin del mundo fortificado...”, páx. 183, destácase a existencia de elementos "visigóticos" na actual igrexa parroquial.

${ }^{74}$ M. Lucas Álvarez, El Tumbo de San Julián..., doc. núm. 138, páx. 299, ano 1068.

${ }^{75}$ M. Lucas Álvarez, El Tumbo de San Julián..., doc. núm. 6, páx. 73, ano 997.

${ }^{76}$ L. López Quiroga e M. Rodríguez Lovelle, "Un modelo de evolución...”, páx. 181.

77 M. Lucas Álvarez, El Tumbo de San Julián..., doc. núm. 23, páx. 106, ano 982.

78 M. Lucas Álvarez, El Tumbo de San Julián..., doc. núm. 24, páx. 109, ano 982.
} 
un século e medio para ter nova información sobre este lugar: é nun inventario xeral das posesións de Samos de 1125 onde se recolle a villa ubi dicunt Sanctum Vereximum $^{79}$. As referencias permítennos e facer unha reconstrución parcial do obxecto da doazón e por tanto situar este lugar na actual parroquia de San Xoán de Muro, concello de Láncara. Nesa parroquia encóntrase un castro que efectivamente mantén a día de hoxe o nome de Sambreixo, nun monte que cae, na súa ladeira norte, directo sobre o río Neira: esa valgada ten que ser a portione que se menciona no documento de Lucito Lucídiz. Na ladeira sur do outeiro, xusto ao pé, encóntrase a aldea de Sambreixo, a villa ubi dicunt Sanctum Vereximum da que se fala no inventario de 1125 . Unha vez máis o paso dos castros ás aldeas abertas tivo lugar da maneira menos traumática posíbel: o novo núcleo nunca se afastou do espazo do seu castro, xurdiu xustamente ao seu carón. Aliás, a actual parroquia de Bande, herdeira do vello mosteiro que nalgún momento mudou a súa advocación orixinal de San Salvador para San Pedro, encóntrase mesmo á fronte, na outra beira do Neira.

$\mathrm{O}$ facto de tanto o castro como a vila levaren o nome dun santo alude a que o paso fundamental para esa transformación no modelo de poboamento foi a cristianización do enclave protohistórico. Non nos chegou, iso si, o templo orixinario; a superficie castro encóntrase a día de hoxe sen ningunha construción en pé. No Plan Xeral de Ordenación Municipal do concello de Láncara ${ }^{80}$ suxírese que a igrexa parroquial de Muro, de características románicas, puido ser trasladada da súa localización orixinal en Sambreixo. Sexa ou non, non estamos ante algo extraordinario. Do castro de San Xoán, que aparece en 997 como sancto Iohane in Cedron $^{81}$, non ficou nin sequera unha ermida: hoxe está cuberto de vexetación e o patrón da parroquia é San Vicente, cuxo templo non se encontra nas inmediacións do outeiro. O topónimo é o único que resta.

Mais non sempre un núcleo de poboación medieval aparecía á beira mesmo do antigo asentamento. Algúns enclaves cristianizados, como o de San Cosme ${ }^{82}$, mantivéronse como advocacións relixiosas menores e non agruparon unha aldea ao seu redor. A día de hoxe aínda é unha humilde capela dedicada a esta advocación a única construción no alto dun castro que, no entanto, mantén un recinto amurallado extraordinariamente ben conservado. Este tipo de emprazamentos non ten a ver, por norma, coa transformación paulatina do modelo de poboación senón máis ben coa apropiación de lugares que permanecían como espazos de

\footnotetext{
${ }_{79}$ M. Lucas Álvarez, El Tumbo de San Julián..., doc. núm. 54, páx. 162, ano 1125.

${ }^{80}$ Plan xeral de ordenación municipal. Concello de Láncara, dipoñíbel en liña: <http://www. planeamentourbanistico.xunta.es/siotuga/documentos/urbanismo/LANCARA/documents/27856ca002. PDF> [Última consulta 11/04/2017].

${ }^{81}$ M. Lucas Álvarez, El Tumbo de San Julián..., doc. núm. 6, páx. 73, ano 997.

${ }_{82}$ M. Lucas Álvarez, El Tumbo de San Julián..., doc. núm. 140, páx. 301, ano 1098.
} 
culto pagán ao longo do tempo mediante a súa modificación e asunción como parte da doutrina cristiá. Rodríguez Fernández inclúeo nunha listaxe de locais, na que se nomean tamén Santa Icía e Formigueiros, entre outros, que terían estado relacionados nun primeiro momento coa explotación mineira romana, que serían abandonados totalmente e que, algúns deles, incluído San Cosme, serían os espazos escolleitos para a erección dunha capela altomedieval ${ }^{83}$.

Lembremos que a diferenza ríxida entre o mundo laico e o relixioso non era aplicábel na altura, como tampouco o límite entre a paz e a guerra. A lexitimidade proviña de Deus, en primeira instancia, e da capacidade de se impor pola forza, despois, de aí que tal fortaleza debía ser exhibida. Isto explica que das construcións non relixiosas non se deba descartar un aspecto, nin até unha funcionalidade, militar ou defensiva ${ }^{84}$. Hai un documento interesante, datado en 1096, en que no medio dun preito entre o mosteiro de Samos contra Pedro Froilaz e Adosinda Díaz se di que: et dicente ababte, quia invenerat inde testamentum in illa torre de Samanos $^{85}$. O testamento non estaba nun simple edificio de Samos, ou nas instalacións do mosteiro en xeral. Estaba na torre de Samos. A simple escolla terminolóxica é por si mesma ilustrativa.

Mais retomando os castros, apuntaremos un último caso que abre o campo a unha dúbida que non estamos en condicións de resolver aínda. Primeiramente, porque é unha das poucas mencións castrais que non foi posíbel localizar con certeza pola falta de contexto na explicación do lugar, aínda sendo probábel que se trate do castro sobre a aldea de Santo Adrián, na parroquia de San Pedro da Pobra do Brollón, no concello do mesmo nome, que hoxe se encontra sen edificación ningunha. En segundo lugar, polo enigmático da mención: sanctum Adrilanum/ in illo monte cum suo castro in circuitu, quomodo est conclusum in testamento de domno Veremudo maiore hic testo ${ }^{86}$. Esa é a única información que temos do lugar en cuestión, no medio dunha longa serie de propiedades de diversa índole que un tal Vermudo Sunilani doa ao mosteiro samonense por volta de 1009. "Santo Adrián no monte co seu castro arredor". Parece ter sido, novamente, o resultado da cristianización dun castro cuxas estruturas defensivas permanecían, cando menos parcialmente, en pé. Mais neste caso semella evidente que a maxestosidade era un dos efectos buscados. Fica por resolver se estamos como na maioría dos casos simplemente ante a apropiación dun espazo cercado, con todo o significado que iso implica porén funcionando apenas como adro, ou se talvez houbese algo máis

\footnotetext{
83 T. Rodríguez FernándeZ, "El fin del mundo fortificado...”, páxs. 181-183.

${ }^{84}$ Sobre a defensa de igrexas e mosteiros neste período ver A. IsLA FrEZ, La sociedad gallega..., páxs. 124-128.

${ }^{85}$ M. Lucas Álvarez, El Tumbo de San Julián..., doc. núm. 145, páx. 306, ano 1096.

${ }^{86}$ M. Lucas Álvarez, El Tumbo de San Julián..., doc. núm. 58, páx. 171, ano 1009.
} 
de intencionalidade e o templo se percibise como unha sorte lugar de poder, e estivese por tanto fechado por calquera tipo de estrutura que trascendese a ruína e lle dese un aspecto máis ou menos militarizado.

\section{O CASTRO NO ASENTAMENTO CAMPESIÑO}

Obviamente non todos os castros contaban cun simbolismo ou cun emprazamento tan interesante como para seren aproveitados por un axente social para exercer o seu poder. Nin todos eles son límites e referencias paisaxísticas, nin teñen unha ermida ou un castelo enriba. Xa se ten dito no comezo deste traballo que a porcentaxe de emprazamentos é moi alta nesta rexión do Lugo central. En Galiza, as distintas estimacións oscilan no número de milleiros ${ }^{87}$. De todas as villae que naceron en, ao pé, ou próximas a un castro, só algunhas recollen e manteñen o transparente nome de Castro ou derivados seus, e mesmo así, daquelas que si que o fan, sobreviven a día de hoxe segundo o Nomenclátor oficial da Xunta nun total de 484 entidades de poboación ${ }^{88}$, sen contar a toponimia menor. Para esta área, tense proposto que un $8 \%$ dos hábitats abertos construíronse exactamente enriba do castro, mentres que no resto de circunstancias o que acontecía era ou ben a aldea crecese extramurallas do castro, ben próxima ao castro porén non pegada a el ou ben que a zona se abandonase por completo, nunha proporción de aproximadamente o $30 \%$ cada unha das casuísticas ${ }^{89}$. Na maioría dos casos, por tanto, os castros tiveron de ser con naturalidade integrados nos espazos agrarios campesiños.

O castro de Sambreixo efectivamente tivo un templo a San Breixo no topo, mais a documentación mostra como parte da súa superficie estaba a ser tratada como terra de cultivo, de aí que o obxecto da doazón que analizamos con anterioridade fosen tres portiones que ían do castro até o río ${ }^{90}$ : iso era unha parcela para ser traballada. Do mesmo modo, o castro de Andreade, no concello de Paradela, estaba plantado con maceiras a comezos do século $\mathrm{XI}^{91}$ e cen anos máis tarde o castrum quod ab antiquis Aliariz vocatus est, na parroquia de Calvor, en Sarria,

\footnotetext{
$\overline{87}$ A. Bounier, Galicia: Ensaio xeográfico..., páx. 1172.

${ }^{88}$ Nomenclátor de Galicia. Toponimia oficial das provincias, concellos, parroquias e lugares, dipoñíbel en liña: $<$ http://www.xunta.gal/nomenclator?p_p_id=NomenclatorPortlet_WAR_NomenclatorPortlet\&p_p_ lifecycle $=1 \& p \_p \_s t a t e=$ normal\&p_p_mode $=$ view $\& p \_p \_c o l \_i d=c o l u m n-1 \& p \_p \_c o l \_c o u n t=2 \&$ resultadosNavPax $=5 \&$ concello $=\&$ parroquia $=\&$ lugar $=$ castr $\&$ provincia $=0 \&$ orde $=1 \&$ ordeInverso $=$ non $>$ [Última consulta 19/09/2017].

89 T. Rodríguez Fernández, "El fin del mundo fortificado...", páx. 181.

90 M. Lucas Álvarez, El Tumbo de San Julián..., doc. núm. 23, páx. 106, ano 982.

91 "in castro Andriadi et in montibus de Riaticos et in Vineales VI mazanales medietate et que comparavimus de Iulia et de suo iermano Gontigio", M. Lucas Álvarez, El Tumbo de San Julián..., doc. núm. 129, páx. 281, ano 1009 .
} 
era atravesado ao medio por unha estrada ${ }^{92}$. Os nomes son antigos, os usos son novos. Pola súa banda, os que estiveron habitados, sexa con núcleos de poboación ben mesmo enriba do castro ben a escasos metros, non sempre foron xestionados por intereses de poderes nobiliarios ou eclesiásticos. En ocasións, as propias comunidades foran quen de manter certa autonomía ao longo do tempo a pesar das mudanzas sociais. As casuísticas son moitas e diversas.

En 854, o presbítero Godesteus pon baixo xurisdición de Samos a igrexa que construíu para San Mamede e San Román nunhas terras que herdou por vía familiar. Na fundación de dito templo dotouno, ademais de con ornamentos como un cáliz ou unha casulla, cunha serie de terras e herdades entre as que se inclúe terras nominibus Uncani agro II modios seminatura ${ }^{33}$. Esta é a primeira vez que se deixa ver nos textos o lugar que hoxe coñecemos como Santa María de Castroncán, no concello de Samos. Aparece nomeado, nese caso, como terras entre as cales é obxecto de doazón un agro concreto. A seguinte mención é case oitenta anos posterior, de 933, e fálasenos nesta ocasión xa non dunhas terras senón dunha villa chamada Uncani ${ }^{94}$. Concretamente, o rei Ramiro II tivo de tomar cartas nun conflito entre os veciños das villis qui nuncupantur Uncani ac Paschasi e o mosteiro de Samos, por ocuparen estes parte dunhas terras que o cenobio consideraba súas. Como na maioría destes casos, polo menos daqueles casos que os mosteiros tiveron a ben conservar, Samos foi beneficiado e os dous enviados do monarca (ou tres, se atendemos ás confirmacións do documento) restabeleceron e confirmaron os marcos. Máis aló do conflito, que se encaixa na dinámica xeral de acumulación de terras por parte dos mosteiros en base á presión sobre o campesiñado libre, temos entón unha vila con nome propio e cunha comunidade aparentemente cohesionada, activa socialmente e resistente fronte os tentativas expansivas samonenses.

A vila chamada Uncani pasa a ser, por vez primeira, Castro Unchani, no ano $1020^{95}$. Neste documento o abade Diego doa, canda todas as posesións vinculadas ao seu mosteiro de Santo Antolín, unha villa en Castro Uncani, que fora do conde Paio Suárez e que el comprara do seu fillo Mendo Páez. O termo villa aquí mostra unha vez máis a súa polisemia: se en 933 Uncani aparece como unha vila no sentido de aldea, unha comunidade rural asentada nun determinado núcleo, nesta ocasión é apenas unha parte, descoñecemos de que características, do mesmo lugar de Uncani, caracterizado agora como castro. En 1058 o topónimo reaparece

\footnotetext{
92 "et inde quomodo interdictum vadit ad illum sautum de Menendo Dautiz, deinde per illam stratam que vadit super illud castrum quod ab antiquis Aliariz vocatus est, et inde per med $\backslash \mathrm{i} / \mathrm{o}$ monte Cremado", M. Lucas Álvarez, El Tumbo de San Julián..., doc. núm. 135, páx. 294, ano 1120.

93 M. Lucas Álvarez, El Tumbo de San Julián..., doc. núm. 99, páx. 239, ano 854[?].

94 M. Lucas Álvarez, El Tumbo de San Julián..., doc. núm. 46, páx. 143, ano 933.

95 M. Lucas Álvarez, El Tumbo de San Julián..., doc. núm. 15, páx. 91, ano 1020.
} 


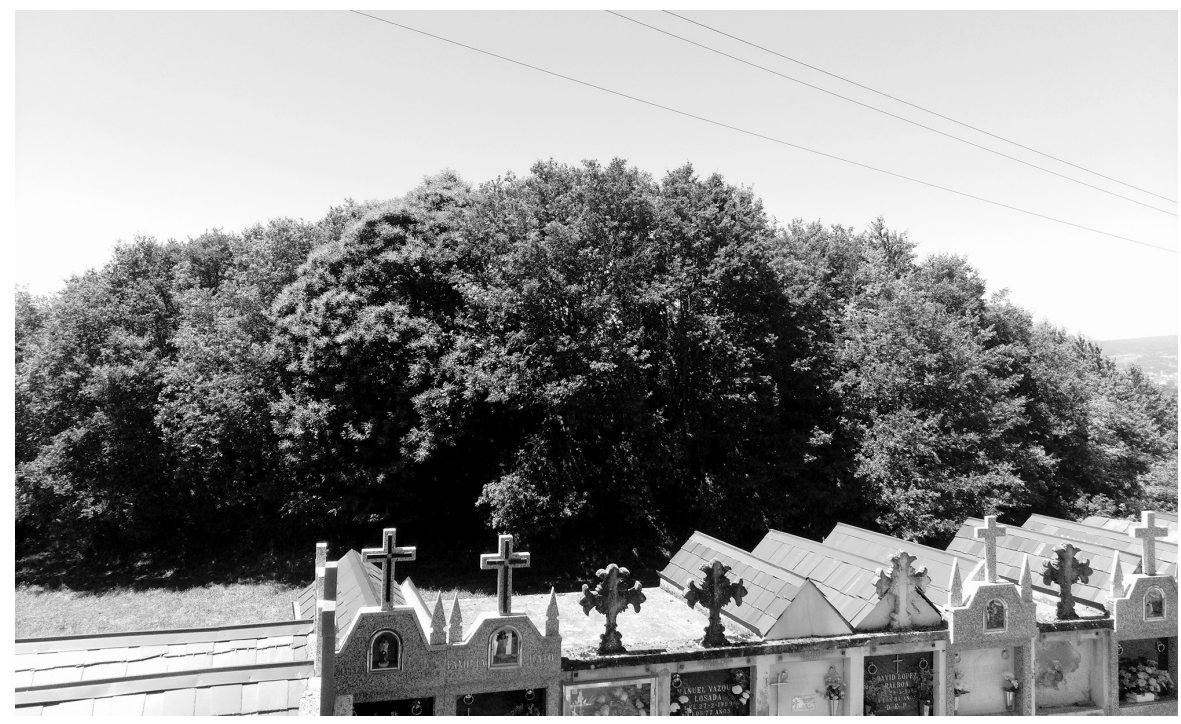

Fig. 3. Vista desde a igrexa de Santo Estevo de Calvor do recinto do Castro Astórica cuberto de árbores autóctonas.

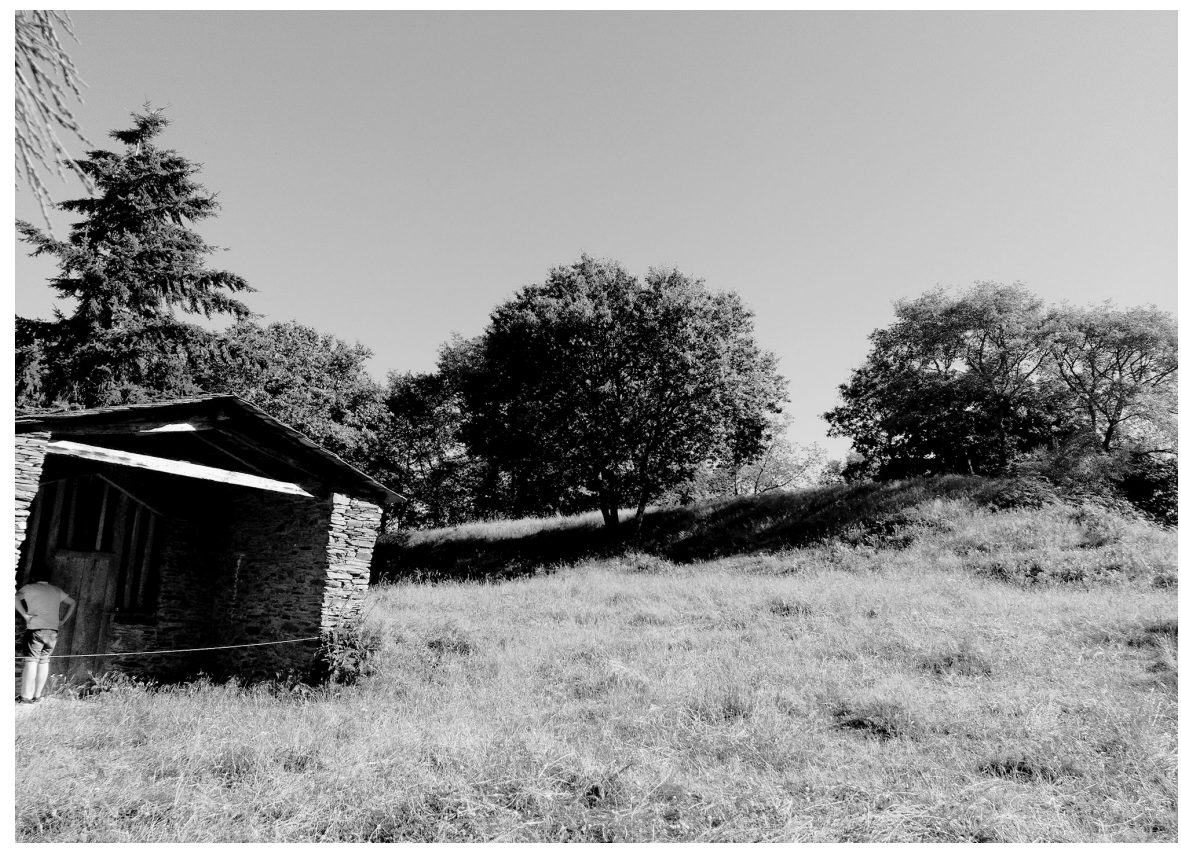

Fig. 4. Actual ermida de San Cosme e muralla do castro, que chega a medir varios metros de altura. 
acompañado por primeira vez dunha advocación relixiosa como Santa Maria de Castruncam $^{96}$ e en 1064 e 1098 témolo só como Castroncan ${ }^{97}$. Os termos castro e Uncani fusionáronse para dar lugar a unha forma romanizante que se fixaría e chegaría até nós case inalterábel; nunca máis encontraremos o termo Uncani ou Unchani independentemente. A aparición da entidade acompañada dunha advocación fálanos da evolución das villae no lento camiño cara a se converteren en parroquias, espazos ben acoutados e encadrados nunha sociedade plenomedieval en que os poderes eran xa quen de se imporen sobre o territorio e sobre as persoas. A finais do século XII Santa María é substituída por Santa Marta, a patroa actual, aparecendo o nome definitivo de Sancta Marthe de Castroncan en $1195^{98}$.

Estamos nun caso en que documentación medieval, toponimia actual e análise do territorio coinciden e permítennos ter unha visión relativamente complexa deste emprazamento. En Castroncán houbo, efectivamente, un poboado castrexo, cuxo impacto no relevo é perfectamente visíbel hoxe ben for a simple vista, ben a través de ferramentas topográficas de lectura do relevo. T. Rodríguez Fernández, no marco da clasificación de castros que fai na área de $\operatorname{Samos}^{99}$, sitúao entre aqueles en que o emprazamento orixinal do castro se mantén na aldea cristiá posterior, aínda que esta non ocupa exactamente o interior do castro, senón que crece extramurallas $^{100}$. Na Figura 5 vemos como, efectivamente, a maior parte do núcleo se estende precisamente ao pé do límite exterior do castro, aínda que de maneira significativa a igrexa parroquial e algunha edificación si poderían estar dentro do mesmo. A mudanza principal, segundo este autor, limítase ao facto de as aldeas deixaren de estar amuralladas, porén en canto a situación e morfoloxía dos asentamentos considera que a continuidade é case total ${ }^{101}$. A data en que se daría este paso sitúaa fundamentalmente no século $\mathrm{V}$, catrocentos anos antes da nosa primeira mención.

En calquera caso, até mediados do século XI, o castro mantén o seu nome orixinario. Descoñecemos a etimoloxía de $U n c a n i^{102}$, mais parece factíbel que nos

\footnotetext{
${ }_{96}$ M. Lucas Álvarez, El Tumbo de San Julián..., doc. núm. 246, páx. 430, ano 1058.

${ }^{97}$ M. Lucas Álvarez, El Tumbo de San Julián..., doc. núm. 130, páx. 284, ano 1064; M. Lucas Álvarez, El Tumbo de San Julián..., doc. núm. 140, páx. 301, ano 1098.

${ }_{9}$ M. Lucas Álvarez, El Tumbo de San Julián..., doc. núm. 53, páx. 155, ano 1175; M. LuCas Álvarez, El Tumbo de San Julián..., doc. núm. 49, páx. 147, ano 1195.

99 Este autor considera que a mudanza do hábitat castral ao hábitat en aldeas abertas se debe non á romanización, senón á cristianización, que se vincula directamente no caso galego coa expansión do priscilianismo. T. Rodríguez Fernández, "El fin del mundo fortificado...”.

${ }^{100}$ T. Rodríguez Fernández, "El fin del mundo fortificado...”, páx. 181.

${ }^{101}$ T. Rodríguez Fernandez, “El fin del mundo fortificado...”, páxs. 153-189.

${ }^{102}$ Un posíbel étimo sería o verbo latino unco, 'soar, facer ruído'. Non se pode descartar outras posibilidades, como por exemplo que se trate dun antropónimo. O investigador alemán Henri Diament, con certeza descoñecendo a información con que estamos a traballar, considerou Castroncán como unha fusión dos substantivos comúns "castrón" e "can". Henri Diament, The Toponomastic Reflexes of Castellum and Castrum: A Comparative Pan-Romanic Study, Heidelberg, Winter, 1972, páx. 73.
} 


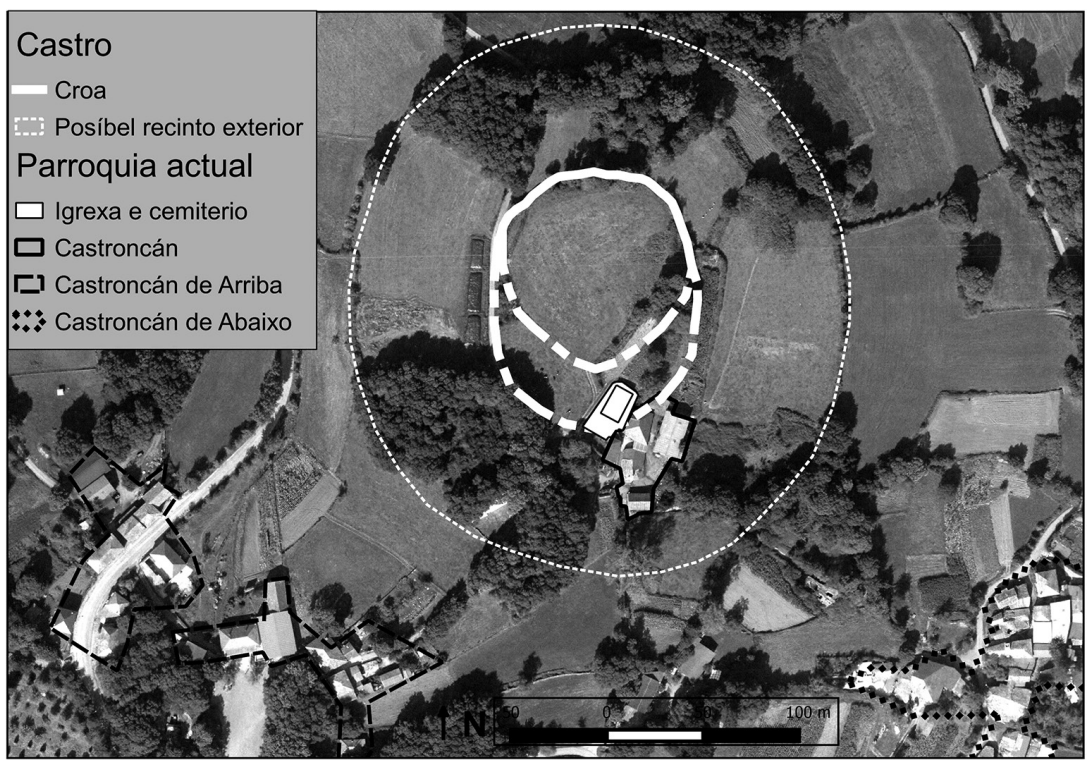

Fig. 5. Santa Marta de Castroncán. Mapa base: PNOA-124 (2015).

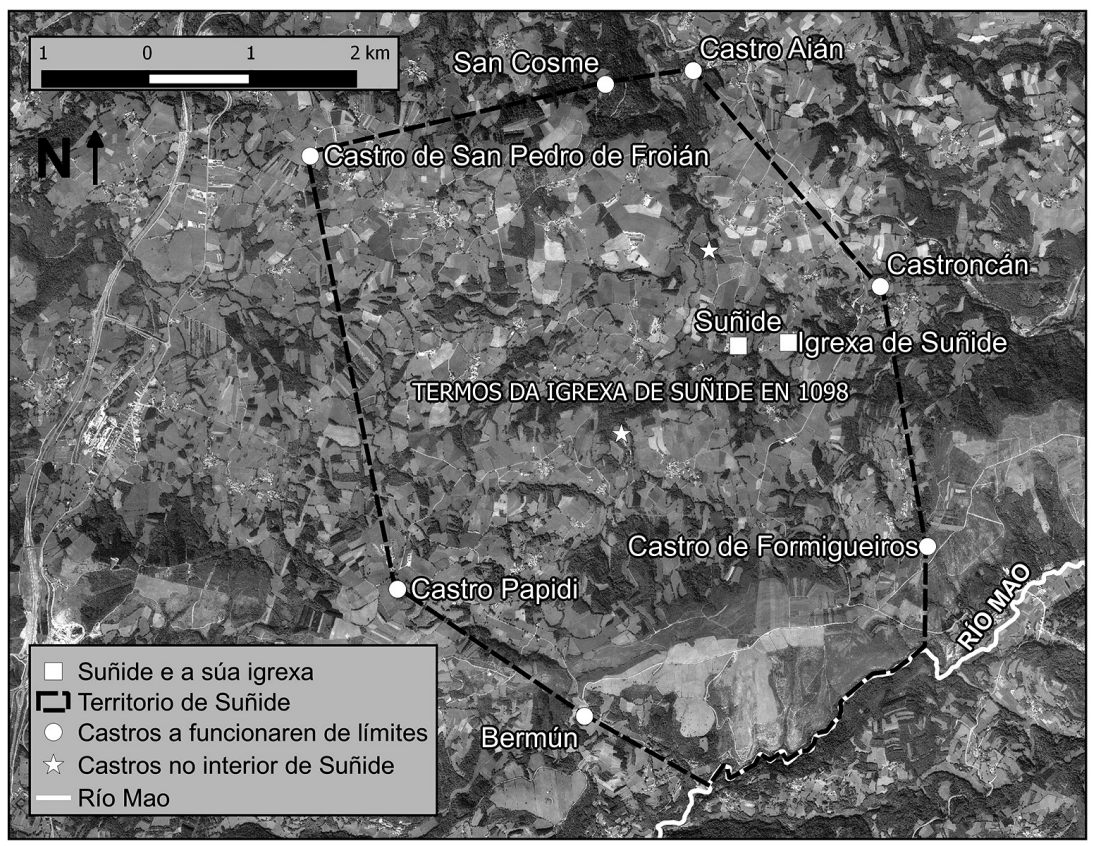

Fig. 6. Termos da igrexa propia de Santa María de Suñide en 1098. Mapa base: PNOA-129 (2015). 
documentos de 854, 933 e 1020 se tratase do topónimo do castro, independentemente de nos dous primeiros o termo castrum non aparecer. Iso non nos fala, de ningunha maneira, de que o castro se crease en 1020, cando aparece nomeado como tal por primeira vez, senón de que Uncani, como nome do castro antigo, se traspuña con normalidade ás terras de labranza do seu entorno ou á aldea que se xestou ao seu pé. O castro definía o territorio. Só é na metade central do século XI, entre 1020 e 1058, que o nome propio se fusiona co nome común da realidade á que nomeaba, suxerindo que habitualmente se empregaban xuntos, para así xurdir xa o romanceado Castroncán que se consolidaría no tempo. O topónimo orixinario Uncani sobreviviu até a Idade Media e despois evolucionou e deu como resultado Castroncán, que remarca a súa natureza castral; consolidouse cando se creou a rede parroquial e chegou vivo até hoxe.

Temos pois un castro, cunha croa claramente definida no seu lado norte e de maneira menos nítida no sur por causa da actividade humana ${ }^{103}$, cun nome propio que vén de antigo, que serve para el e para o espazo que o rodea e que se mantén vivo até hoxe, coa igrexa parroquial e o cemiterio encostados mesmo na croa, co núcleo principal ao pé da igrexa, anexo ao emprazamento orixinal, e xa separadas do vello recinto, aínda que moi próximas, dúas aglomeracións nomeadas con topónimos replicantes do xeito usual para poboacións secundarias xurdidas dunha principal anterior: Castroncán de Arriba e Castroncán de Abaixo. As continuidades entre o hábitat castrexo e os hábitats campesiños medievais non se ven só nas ocupacións tardías que os materiais poden constatar, no caso desta área até o período suevo, vense aínda vivamente na documentación medieval que nos chega desde o século IX e nos demostra que podemos encontrarnos ante procesos de transformación lentos e suaves, contrarios á idea de brusquidade. A longue durée ante os nosos ollos.

\section{Conclusións}

Nun documento datado en 1098 un Pedro García doa a Samos a metade da súa igrexa propia de Santa María de Suñide, cos seus numerosos lugares anexos, e explica con detemento os límites e a composición deste espazo. Deixando fóra os agregados, a área dependente directamente do templo tiña un tamaño moi considerábel, abranguendo non só a Suñide actual senón varias das parroquias

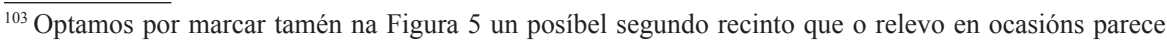
insinuar e a fotografía aérea non descarta, especialmente o voo americano dos anos 56-57, a pesar de non ser máis que unha hipótese non demasiado sólida, entre outras cousas porque contaría cun diámetro moi por riba da media. A nosa intención non é propor a existencia da estrutura, senón animar a que se realicen traballos que permitan que a posibilidade se descarte ou confirme, ao acharmos que a particularidade do lugar paga a pena do esforzo de facer análises arqueolóxicas específicas.
} 


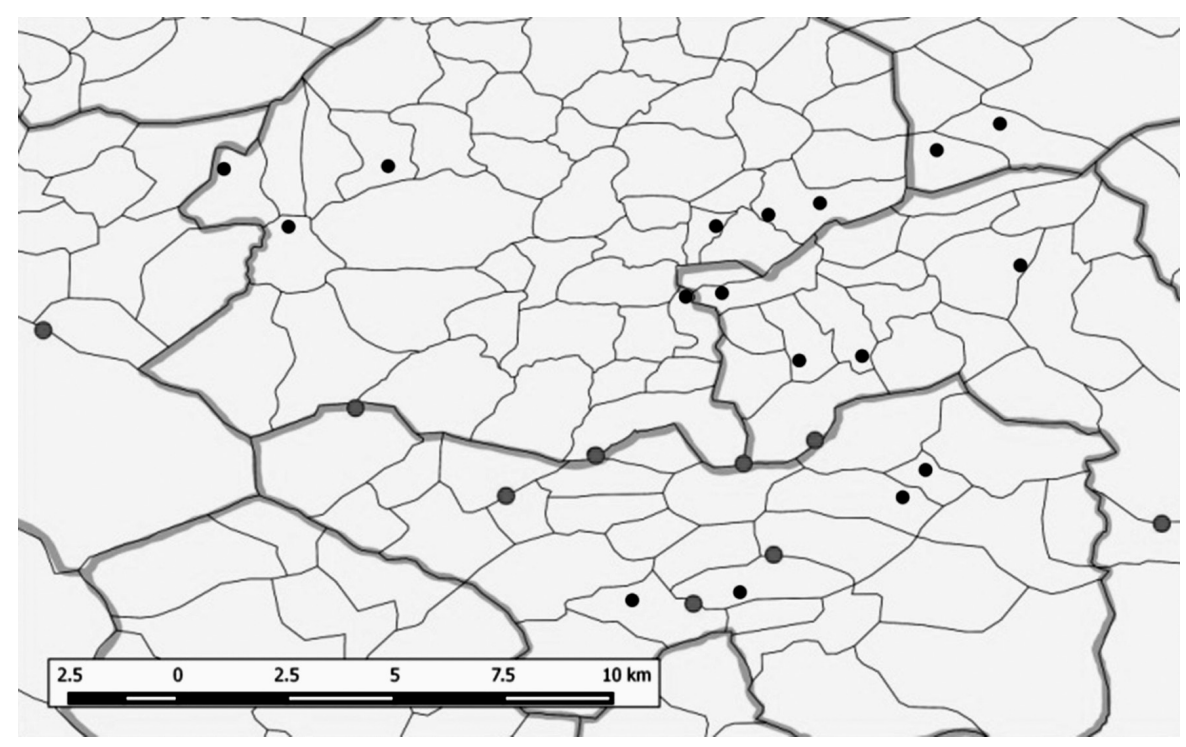

Fig. 7. Coincidencia dos castros mencionados no tombo de Samos cos límites parroquiais na actualidade.

lindeiras. Dentro dos límites que se propoñen ficarían incluídas villae que xa están documentadas como tales ben antes desta altura, xa case no século XII. Achamos por tanto que, como se afirma no propio texto, estase a falar dun marco espacial ao que se fai referencia nese momento porén que chega de longo tempo atrás:

et est ipsa ecclesia terminata sicut determinat per terminos antiquos, id est: per terminos de Veremudi, per castro Papiti, per sancto Petro de Froian, per sancto Cosme, per castro Eilani, per Ceseirola, per Castrocan, per castro Formicarios, per rivulum de Humano ${ }^{104}$.

Sen entrarmos con detemento na natureza precisa desa vila de Suñide, si podemos afirmar que ocupaba un lugar preeminente na pequena depresión en que se encontra, formada por regatos que corren cara ao norte e verten finalmente no Sarria. A amplitude do espazo descrito parece ter máis a ver cun resquicio dos extensos espazos altomedievais que do modelo de compartimentación e híper regulación do terreo feudal. Porén, o que realmente fai este documento excepcional é o facto de que todos e cada un dos nomes que se dan como marcos, agás a non

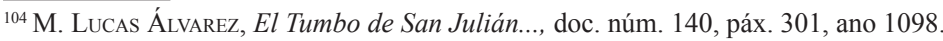


identificada Ceseirola ${ }^{105}$ e obviamente o río Mao, son castros. Eles foron a base sobre a que se construíu a nova territorialidade e, se callar, fai sentido pensar que a igrexa de Suñide é herdeira en certa maneira dun territorio castral, talvez do dun dos dous castros que se encontran dentro da área delimitada.

Este documento sintetiza en certa maneira todo o que se vén de expor ao longo do artigo. Por unha banda, e en primeiro lugar, os castros funcionan de maneira xeneralizada como fitos clave na organización do territorio, cunha especial significación fronte a calquera outro elemento humano ou natural, apoiados nunha tradición aceptada e recoñecida polo conxunto da sociedade. Tal tradición viña de lonxe e tivo unha longa proxección cara ao futuro: na Figura 7 superponse a rede parroquial actual coa localización de boa parte dos castros mencionados no tombo de Samos ${ }^{106}$; non sorprende ver como no emprazamento de moitos deles divídense aínda hoxe dúas ou máis parroquias. As cifras aumentan considerabelmente se, no canto de só os que están no lugar exacto dos límites, contamos tamén aqueles que se encontran próximos aos mesmos, nos espazos de transición dunha comunidade campesiña a outra ${ }^{107}$.

Mais ao mesmo tempo tamén podemos ver como nos encontramos ante o resto do que foi e xa non era. Estes enclaves daban forma á paisaxe coa súa presenza, os seus vellos territorios asociados eran recoñecidos, o seu significado era potente, mais os castros xa non existían como tais. Castroncán, como vimos, estaba reconvertido nun asentamento campesiño, igual que Bermún ${ }^{108}$, aldea que aínda na actualidade se encontra xusto no interior das murallas do antigo castro; San Cosme era o terreiro dunha capeliña; o castro de Aián con toda probabilidade era explotado como espazo agrario e Formigueiros mantíñase alí, impoñente no alto cos seus varios niveis de murallas, a pesar de que a vila de Formigueiros había xa tempo que se constituíra ao seu pé, como se construíu San Pedro de Froián á beira do seu castro e Santa Icía ao pé de Castro Papidi.

Nos séculos X e XI é o tempo das villae: o desencastelamento está completado e a relativa lasitude e desorganización dos lugares habitados, agora abertos e afastados dos altos cumios, axiña había de se converter no sistema de parroquias ben

\footnotetext{
${ }^{105}$ É posíbel que se trate do espazo agrario e de monte coñecido como As Coirás, que se encontra a medio camiño precisamente entre Aián e Castroncán.

${ }^{106}$ Coa excepción só daqueles que non foi posíbel localizar con certeza e os que fican fóra por cuestión de escala.

${ }^{107}$ Sería interesante, de cara a traballos futuros, realizar esta superposición dos emprazamentos dos castros cos límites parroquiais baseándonos non só naqueles mencionados documentalmente senón en todos os que están catalogados no rexistro arqueolóxico. Iso axudaríanos a ver até que punto a función delimitadora é esaxerada pola natureza das fontes e oculta moitos outros castros, por non actuaren de límites, mais que igualmente podían ser significativos a outro nivel.

${ }^{108}$ Este lugar é o único na enumeración do que se indica que o linde pasaría polos seus termos e non necesariamente polo propio castro.
} 
definidas e controladas polos poderes feudais que chegarían, case intactas, até o longo século XX galego. Os lugares de habitación, os marcos de apropiación dos bens e de traballo sobre a contorna son, nitidamente, orixinais. Mais no entanto a pegada dos castros nunca foi borrada. As primitivas terras vinculadas a eles foron a base sobre a que se construíu a nova territorialidade. Os vellos poboados amurallados sobreviviron como lugares de memoria, os seus emprazamentos mantiveron relevancia na concepción colectiva do mundo e foron por tanto escolleitos como lugares para a erección de igrexas; foron tamén feitos fronteira. Convertéronse no escenario do relato.

Ficou por ver só como encaixados nesa nova orde se erixirían os novos castelos, cunha natureza e uns obxectivos tamén novos, moi lonxe de seren unha evolución directa dos antigos modelos de fortificación.

\section{BIBLIOGRAFÍA}

Almeida, Carlos A. Ferreira de, "Castelos medievais no noroeste de Portugal", en Fernando Acuña Castroviejo (coord.), Finis Terrae: Estudios en lembranza do Pr. Dr. Alberto Balil, Santiago de Compostela, Universidade de Santiago de Compostela, 1992, páxs. 371-385.

Almeida, Carlos Alberto Ferreira de, Alto Minho, Lisboa, Presença, 1987.

Andrade Cernadas, José Miguel, "Villas regias y asembleas judiciales entre los siglos X y XI: el caso de Larín”, Revista Signum, 12 (2011), vol. II, páxs. 18-35.

Andrade Cernadas, José Miguel, O Tombo de Celanova: Estudio introductorio, edición e índices, 2. vols., Santiago de Compostela, Consello da Cultura Galega, 1995.

Ares Vázquez, Nicandro, "Toponimia do concello de Triacastela”, Lvcensia. Miscelánea de Cultura e Investigación, 47 (2013), vol. XXIII, 297-306.

Arizaga Castro, Álvaro e Ayán Vila, Xurxo, "Etnoarqueología del paisaje castreño: La segunda vida de los castros", en Francisco Javier Fernández García et al. (eds.), Los pueblos de la Galicia céltica, Madrid, Akal, 2007, páxs. 445-531.

Ayán Vila, Xurxo, "Os castros despois dos castros: Un espazo simbólico na paisaxe rural tradicional galega", en Paula Ballesteros Arias (coord.), Encontros coa etnografía, Noia, Toxosoutos, 2005, páxs. 63-136.

Baliñas Pérez, Carlos, "As orixes altomedievais da Terra e Condado de Lemos”, en Anselmo López Carreira (ed.), O Condado de Lemos na Idade Media. I Simposio de Historia en Terra de Lemos, Monforte de Lemos, Xunta de Galicia, 2008, páxs. 19-24.

Baliñas Pérez, Carlos, Do Mito á Realidade. A Definición Social e Territorial de Galicia na Alta Idade Media (Séculos VIII e IX), Santiago de Compostela, Fundación Universitaria de Cultura, 1992.

Barroca, Mario, "Prope litore maris: O sistema defensivo da orla litoral da Diócese do Porto", en Carlos Amaral (coord.), Um Poder entre Poderes. Nos 900 Anos da Restauração da Diócese do Portoe e da Construção do Cabido Portucalense, Porto, Universidade Católica Portuguesa - Cabido Portucalense, 2017, páxs. 197-246. 
Barroca, Mário, "Fortificações e povoamento no norte de Portugal", Portugalia, 25 (2004), páxs. 181-204.

Bollnow, Otto Friedrich, Hombre y espacio, Barcelona, Labor, 1969.

Bouhier, Abel, Galicia: Ensaio xeográfico de análise e interpretación dun vello complexo agrario, Santiago de Compostela, Consellería de Agricultura, Gandaría e Política Agroalimentaria - Caixanova, 2001.

Boullón Agrelo, Ana, Antroponimia medieval galega (ss. VIII-XIII), Tubingen, Niemeyer, 1999.

Buscador de Topónimos. Xunta de Galicia, dispoñíbel en liña: <http://toponimia.xunta.es/ Buscador>.

Diament, Henri, The Toponomastic Reflexes of Castellum and Castrum: A Comparative Pan -Romanic Study, Heidelberg, Winter, 1972.

Fernández Abella, David, "Castro Valente, una fortificación de control del río Ulla" en Raúl Catalán, Patricia Fuentes e José Carlos Sastre (eds.), Fortificaciones en la tardoantigüedad: élites y articulación del territorio (siglos V-VIII d.C.), Madrid, La Ergástula, 2014, páxs. 393-398.

Fernández Pereiro, Mario, "Mais lá da Cultura Castreja: castros ex-novo durante a antiguidade tardia no noroeste da Gallaecia" en Alia Vázquez Martínez et al. (eds.), (Re)escribindo a Historia: Achegas de novos investigadores en Arqueoloxía e Ciencias da Antigüidade, Santiago de Compostela, Andavira, 2017, páxs. 287-292.

García de Cortázar, José Ángel, “Organización del espacio, organización del poder entre el Cantábrico y el Duero en los siglos VIII a XIII", en José Ángel García de Cortázar (ed.), Del Cantábrico al Duero. Trece estudios sobre la organización social del espacio en los siglos VIII al XIII, Santander, Universidad de Cantabria, 1999, páxs. 15-48.

González Paz, Carlos Andrés, “ 'Castrum et castellum': algunos ejemplos del marco altomedieval gallego", en Amador Ruibal Rodríguez (coord.), Actas del III Congreso de Castellología Ibérica: 28 de octubre - 1 de noviembre, Guadalajara, Asociación Española de Amigos de los Castillos - Diputación de Guadalajara, 2005, páxs. 107-122.

Gurievitch, Aron, As Categorias da Cultura Medieval, Lisboa, Caminho, 1991.

Gutiérrez González, José Avelino, "Del Castrum al Castellum. Los castros entre la Antigüedad y la Edad Media”, en Miguel Ángel de Blas Cortina e Ángel Villa Valdés (coords.), Los poblados fortificados del noroeste de la Península Ibérica: Formación y desarrollo de la cultura castreña. Coloquios de Arqueología en la cuenca del Navia. Homenaje al Prof. Dr. José Manuel González y Fernández-Valles, Navia, Ayuntamiento de Navia, 2002.

Hydace, Chronique, ed. Alain Tranoy, t. I, París, Éditions du Cerf, 1974.

Isla Frez, Amancio, La sociedad gallega en la Alta Edad Media, Madrid, Consejo Superior de Investigaciones Científicas (CSIC), 1992.

Inventario do Patrimonio Arqueolóxico de Galicia, depositado na Dirección Xeral de Patrimonio Cultural da Xunta de Galicia, Santiago de Compostela, inédito.

Lima, Alexandra Cerveira Pinto S., Castro Laboreiro: Povoamento e organização de um território serrano, Melgaço, Instituto de Conservação da Natureza, 1996.

Llinares García, Mar, Mouros, ánimas, demonios: el imaginario popular gallego, Madrid, Akal, 1990. 
López Arias, Xaime Féliz, e López Méndez, Ricardo Segundo, "Organización territorial das terras de Sárria (s. VI a s. XX)", Boletín do Seminario de Estudos Sarriaos "Francisco Vázquez Saco”, 21 (2016), páxs. 105-124.

López Sangil, José Luís e Vidán Torreira, José Manuel, “Tumbo Viejo de Lugo (Transcripción completa)", Estudios Mindonienses. Anuario de estudios histórico-teológicos de la Diócesis de Mondoñedo-Ferrol, 27 (2011), páxs. 11-373.

López Quiroga, Jorge, El final de la Antigüedad en la Gallaecia: La transformación de las estructuras de poblamiento entre Miño y Duero (siglos V al X), A Coruña, Fundación Pedro Barrié de la Maza, 2004.

López Quiroga, Jorge, e Rodríguez Lovelle, Mónica, “Un modelo del poblamiento rural en la Galicia interior (s. V-X): El territorio en torno a la depresión de Sarria y al monasterio de Samos", Boletín do Museo Provincial de Lugo, 9 (1999-2000), páxs. 173-185.

López Quiroga, Jorge, e Rodríguez Lovelle, Mónica, “Castros y castella tutiora de época sueva en Galicia y Norte de Portugal. Ensayo de inventario y primeras propuestas interpretativas", Historia Antiqua, 23 (1999), páxs. 355-374.

Lucas Álvarez, Manuel, El Tumbo de San Julián de Samos (Siglos VIII-XII). Estudio introductorio. Edición diplomática. Apéndices e indices, Santiago de Compostela, Caixa Galicia, 1986.

Martín Viso, Iñaki, Poblamiento y estructuras sociales en el norte de la Península Ibérica (siglos VI-XIII), Salamanca, Universidad de Salamanca, 2000.

Martinón-Torres, Marcos, O megalitismo despois do megalitismo. Arqueoloxía e historia dos megalitos galegos a través das fontes escritas (s. VI-s. XIX), Valga, Concello de Valga, 2011.

Marques, André Evangelista, Da representação documental à materialidade do espaço. Território da diocese de Braga (séulos IX-XI), Porto, CITCEM - Afrontamento, 2014.

Marques, André Evangelista, O casal. Uma unidade de organização social do espaço no EntreDouro-e-Lima (906-1200), Noia, Toxosoutos, 2008.

Nomenclátor de Galicia. Toponimia oficial das provincias, concellos, parroquias e lugares, dispoñíbel en liña: $<$ http://www.xunta.gal/nomenclator?p p id=NomenclatorPortlet WAR NomenclatorPortlet\&p_p_lifecycle $=1 \& p \_p \_s t a t e=$ normal\&p_p_mode $=v i e w \& p \_p \_c o l \_$ $\mathrm{id}=$ column $-1 \& \mathrm{p} \_\mathrm{p} \_$col_count $=2>$

Nora, Pierre (ed.), Les lieux de mémoire, vols. I, II (t. 1-3), II (t. 1-3), Paris, Gallimard, 19841992.

Pallares Méndez, $\mathrm{M}^{\mathrm{a}}$ del Carmen, Ilduara, una aristócrata del siglo X, Sada, Ediciós do Castro, 2004 ( $2^{\mathrm{a}}$ rev. ed. e ampl.).

Penoucos, X. R., "Un incendio descubre un castro en Samos", La Voz de Galicia, 07/11/2017, dispoñíbel en liña: < https://www.lavozdegalicia.es/noticia/lugo/samos/2017/11/07/incendio-descubre-castro-samos/0003_201711L7C7991.htm>

Pérez Gónzalez, Maurilio, Léxico Latinitatis Medii Aevis Regni Legionis (s. VIII-1230), Turnhout, Brepols Publishers, 2010.

Plan xeral de ordenación municipal. Concello de Láncara, dipoñíbel en liña: <http:// www.planeamentourbanistico.xunta.es/siotuga/documentos/urbanismo/LANCARA/ documents/27856ca002.PDF>.

Portela Silva, Ermelindo e Pallares Méndez, María Carmen, "Estructuras agrarias y cambio social en la Galicia de la Edad Media. Una propuesta de lectura histórica del paisaje" en 
Mercedes López-Mayán Navarrete e Carlos J. Galbán Malagón (coords.), Del documento escrito a la evidencia material: Actas del I Encuentro Compostelano de Arqueología Medieval (Santiago de Compostela, 22, 23 y 24 de marzo de 2006), Santiago de Compostela, Lóstrego, 2007, páxs. 37-54.

Portela Silva, Ermelindo e Pallares Méndez, María Carmen, "La villa, por dentro. Testimonios galaicos de los siglos X y XI”, Studia historica. Historia medieval, 16 (1998), páxs. 13-43.

Portela Silva, Ermelindo e Pallares Méndez, María Carmen, "Galicia á marxe do Islam, continuidade das estructuras organizativas no tránsito á Idade Media” en María Xosé Fernández Cerviño e Gerardo Pereira Menaut (coord.), Galicia fai dovs mil anos. O feito diferencial galego na Historia, vol. I, Santiago de Compostela, Museo do Pobo Galego - A Editorial da Historia, 1997, páxs. 435-458.

Portela Silva, Ermelindo, "La articulación de la sociedad feudal en Galicia", en En torno al feudalismo hispanico: I Congreso de Estudios Medievales, León, Fundación Sánchez-Albornoz, 1987, páxs. 333-339.

Quintía Pereira, Rafael, Mariña: de deusa a santa. A advocación de Santa Mariña na cristianización da Gallaecia, Vigo, Galaxia, 2017.

Rodríguez Fernández, Tomás, "El fin del mundo fortificado y la aparición de las 'aldeas abiertas'. La evidencia del Centro-Oriente de Lugo (Samos y Sarria)", Espacio, Tiempo y Formas. Serie I. Prehistoria y Arqueología, 7 (1994), páxs. 153-189.

Sánchez Pardo, José Carlos, Territorio y poblamiento en Galicia entre la Antigüedad y la plena Edad Media, tese de doutoramento publicada en CD, Santiago de Compostela, Servizo de Publicacións da Universidade de Santiago de Compostela, 2008.

Sarmiento, Fr. Martín, Viaje a Galicia (ed. José Luís Pensado, 1975), Salamanca, Universidad de Salamanca, 1745.

Tejerizo García, Carlos e Fernández Pereiro, Mario, Prospección arqueolóxica do poboamento de época tardorromana e sueva no Sueste da Galiza, informe inédito depositado na Dirección Xeral do Patrimonio Cultural, Santiago de Compostela, 2018.

Toubert, Pierre, Les structures du Latium médiéval: Le Latium méridional et la Sabine du IXe siècle à la fin du XIIe siècle, 2 vols., Roma, École Française de Rome, 1973.

Varela Sieiro, Xaime, Léxico cotián na alta Idade Media de Galicia: A arquitectura civil, Santiago de Compostela, Universidade de Santiago de Compostela, 2008. 